Volume 7 | Issue 2

February 2020

\title{
The Segregation of Markets
}

Christian Turner

University of Georgia School of Law, cmturner@uga.edu

Follow this and additional works at: https://scholarship.law.tamu.edu/lawreview

Part of the Banking and Finance Law Commons, Business Law, Public Responsibility, and Ethics Commons, Election Law Commons, and the Law and Politics Commons

\section{Recommended Citation}

Christian Turner, The Segregation of Markets, 7 Tex. A\&M L. Rev. 299 (2020).

Available at: https://doi.org/10.37419/LR.V7.I2.1

This Article is brought to you for free and open access by Texas A\&M Law Scholarship. It has been accepted for inclusion in Texas A\&M Law Review by an authorized editor of Texas A\&M Law Scholarship. For more information, please contact aretteen@law.tamu.edu. 


\title{
ARTICLES \\ THE SEGREGATION OF MARKETS
}

\author{
By: Christian Turner*
}

\begin{abstract}
Campaign-finance reformers fear that rich donors' money can be used disproportionately to influence the content of campaign advertising and thus, perhaps, the results of elections. In European football, UEFA has attempted to ban "financial doping"-rich owners' use of money earned in sectors other than football to pay large sums for the best football players. Campaign-finance reform efforts and "financial fair play" rules in sport may seem like bespoke solutions to different problems. In fact, they are the same solution to the same problem. Both are attempts to ensure that power accumulated in one market is not brought into another market so as to distort and damage its proper functioning. Market segregation, which seeks to bar explicit or implicit trans-market "currency" exchanges, disconnects the markets' decisionmaking rationales. By understanding the segregation regulatory tool and its characteristic difficulties, including the appearance of black-market currency exchanges and the entrenchment of incumbents, it is possible to see in more general terms the challenges in many other legal settings, including moral rights and socalled "repugnant transactions."
\end{abstract}

\section{TABle of CONTENTS}

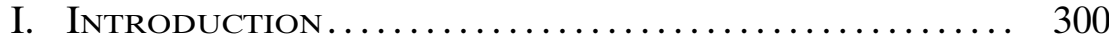

II. The Problem .............................. 305

A. The Strong Market-Ontology School ............ 306

B. The School of Discrete Spheres ............... 311

C. The Institutional Models Approach ............. 314

1. Currency Definition ................... 316

2. Decision Rules.......................... 317

3. Redistribution Rules ..................... 317

4. Secondary Influence Markets ............. 318

5. Currency Exchange and Segregation Rules ..... 320

* Associate Professor, University of Georgia School of Law. The ideas in this Article have resulted from countless conversations over the last few years. For these, I am indebted to Guido Calabresi, Harlan Cohen, Christopher Elmendorf, Deborah Hellman, Gregory Klass, Michael Madison, Joseph Miller, Michael Pappas, and Lori Ringhand. I would like to thank the participants at the University of Maryland Legal Theory Workshop, UGA faculty brownbag, especially Elizabeth Burch and Usha Rodrigues, for their helpful comments on a much earlier draft, the participants at the Fourth WINIR Conference held at Utrecht University, and especially Rutger Claassen for his very thoughtful comments and literature suggestions, and the participants at the 2016 conference of the Association of Law, Property, and Society held at Queen's University in Belfast. For their invaluable research assistance, my thanks go to Justin Van Orsdol, Sam Weaver, and Ahsan Habib. I am also grateful for the thoughtful, careful, and constructive assistance of Jenna Johnson and the editors of the Texas A\&M Law Review.

DOI: https://doi.org/10.37419/LR.V7.I2.1 


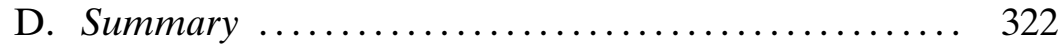

III. Some Examples................................ 323

A. Financial Fair Play......................... 324

1. A Rough Description of European Football

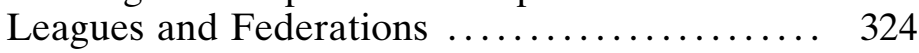

2. Key Market Attributes ................. 326

3. UEFA's Financial Fair Play Regulations ....... 328

B. Campaign Finance Reform Efforts .............. 333

C. The General Pattern ......................... 340

IV. Moral Rights and Other Puzzling Markets ..... 341

V. Segregation as a Choice ..................... 346

VI. Conclusion ................................. 348

[I]t is the meaning of goods that determines their movements. ${ }^{1}$

- Michael Walzer

\section{INTRODUCTION}

A common way to think about the legal system is as a publicly administered set of rules that ultimately regulates behavior in "the market" or in some set of private spheres. From this point of view, there is, on the one hand, natural human interaction proceeding under the rules of society and, ultimately, of physics. On the other hand, there are the purpose-built rules made by public institutions and applied to disputes, rules that claim authority over the various forces internal to the market. When the market processes would, if unmolested, lead to bad results, the case for public regulations becomes stronger. And so modern regulatory theory centers on identifying bad market outcomes, often in neoliberal terms, and assessing whether regulatory interventions might improve on them.

I follow a different course in this Article. There is not one thing that is the market and then another that is the public regulatory apparatus. There is instead just a set of cooperating people, and there are many, many overlapping subsets of this group of people that all function as decisionmaking entities, "markets," that are each subject to the potential influence of all the other markets. Seen in this way, a society is a collection of markets, the participants in each of which interact under collectively enforced rules respecting the relative power that the market assigns them.

An individual market is, like the whole society of which it is a part, a cooperative enterprise. Its organization has some cooperative purpose. In sum, a market is a subset of a society that is ultimately intended to decide some discrete things. Indeed, when we casually use the word "market," we do so to describe not the totality of the attrib-

1. Michael Walzer, Spheres of Justice: A Defense of Pluralism and Equality 8 (1983). 
utes and activities of its participants but the mechanisms for their cooperation regarding these decisions. Through markets of various kinds, we decide how many and what kinds of televisions to produce, how much to invest in research and development of a particular technology, whom to educate and in what way, and which people should serve as public representatives. Whether through dollars, votes, or unilateral command, power is deployed in diverse ways within the group's many markets and variously aggregated in each of them to reach decisions. ${ }^{2}$

It is natural to wonder how all these markets might best interact, given that their purposes and mechanics might not always be sympathetically aligned. For example, the market in cars functions both to direct social resources to producing the right number and types of cars and to allocate them to individuals, subject to those individuals' and society's relative desires for other goods. ${ }^{3}$ It is sensible to connect this market seamlessly with other markets in material (and some non-material) goods for two reasons. First, car production comes at the expense of other forms of production, and information must therefore be exchanged between markets to coordinate effort. Second, satisfying individual desires in the car market is incentivized by granting people power-in some proportion to their contribution to that satisfaction - to acquire goods in other markets. Car producers need to eat. A common currency for goods (money) and the price mechanism together accomplish the seamless linking between the car market and other markets that serves these functions.

But the purposes of some markets, like the market that produces public legislation, are fundamentally unlike those of the market for cars and would be severely diminished in quality by this sort of direct connection. ${ }^{4}$ We not only use different currencies in the car market and the legislation market, dollars and votes respectively, but we go further and forbid currency exchanges between one and the other. In other words, we segregate these markets by force of law.

I define "segregation" of one market from another to mean regulation, however imposed, that prevents power accumulated in one market from being used as power in the other. Segregation is intended to render the decisionmaking methods of the subject markets causally disconnected from one another. A simple example is a public corrup-

2. As Michael Walzer has put it: "[T]here has never been a single criterion, or a single set of interconnected criteria, for all distributions." Id. at 4.

3. See W. Earl Sesser, Match Supply and Demand in Service Industries, Harv. Bus. REv. (1976), https://hbr.org/1976/11/match-supply-and-demand-in-service-indus tries [https://perma.cc/7DW6-W6XD].

4. No two cooperative instances are identical, and, in some small sense at least, they possess distinct distributive logics. "Every social good or set of goods constitutes, as it were, a distributive sphere within which only certain criteria and arrangements are appropriate." Id. at 10 . But segregation comes at a cost that is not always worth paying in light of the benefits of linkage. See infra Section II.C.5. 
tion law that prohibits a judge from taking a bribe. The market in public justice is thought to perform its function better when power in financial markets does not influence the currencies of power within the public justice market. If a judge cannot accept payment in exchange for a favorable ruling, then financial power cannot be used (directly at least) to affect judicial decisions. With this prohibition, therefore, reasons arising from fear and desire in finance will not by dint of their foundation in material wealth translate automatically to reasons for law. This simple example, because of the rather obvious but indirect ways financial wealth can indeed influence legal outcomes, hints at the complexity and practical difficulty of segregation.

This Article aims to consider how and why markets are segregated from one another. Why do some freely exchange currencies and others forbid it? A common answer might be that I am confusing two types of institutions, exchange-based markets and cooperative institutions. But the distinction between "markets" and other institutions is neither obvious nor so fixed as to be corporeal, and the benefits for at least some forms of analysis of seeing the many forms of human interaction as variations on a central theme are, I will argue, substantial. Therefore, I wish to understand the segregation of markets without resorting to argument by label-that is without simply asserting that one thing is a market while another is not.

Mere definition does no useful work in establishing that a border between institutions should be impervious to power transfer. I will instead recognize the essential similarities among institutional types. Using the same terminology-markets, currency, and power-focuses our attention on what is really distinct among the various subsets of human interaction that compose a society. If we are to conclude that some decisionmaking institutions should be called this and others that, it should be because we have made a defensible conceptual distinction that a terminological schism makes more readily perceptible. The simple binary of market and non-market obscures, as to some basic questions, more than it enlightens.

But why study segregation as a distinct legal mode apart from any other kind of regulation? I argue here that the sort of intervention represented by segregation is qualitatively different from other forms of market regulation in its regulatory purpose and design. Most other types of regulation are designed to avert and to rectify so-called market failures that are internal to the regulated market. For example, regulations aimed at principal-agent problems, regulations intended to avert tragedies of the commons, and regulations counteracting (directly or indirectly) dynamically increasing levels of inequality of market power all combat problems arising within a single decisionmaking structure.

Segregation, in contrast, aims at problems arising from those maldistributions of decisionmaking power that have exogenous causes. 
That is, one way that a market can fail to achieve its purpose is that its decisionmaking calculus is skewed by power accumulated outside the market itself and exchanged for power within it, as in the judicial bribery example above. Regulations internal to the market, focusing on internal market transactions, will likely not be sufficient to solve the problem. Instead, regulations must target the power misallocation by somehow prohibiting currency exchange, the use in the troubled market of power gained elsewhere.

The Article begins, in the next Part, by elaborating the model that I use to contrast segregation and internal forms of regulation. I situate my approach to market definition, what I call the "institutional models" approach, by distinguishing it from the "strong market-ontology school" used by some sociologists and from the "school of discrete spheres" 6 advanced by some distributive justice theorists. The taxonomy of markets I develop turns on: (1) currency definition (representation of decisional power), (2) decision rules, (3) currency redistribution rules, (4) regulation of what I call "secondary influence markets,"7 and (5) currency exchange rules governing when power in external markets can be brought in and used in the market.

In Part III, I turn to examples of market segregation and choose two factually distinct but conceptually similar markets. One is the market for political campaigning. Campaign-finance reform efforts attempt to control the flow of power between the election market and the financial markets, ${ }^{8}$ in other words to shut down the currency exchange between dollars and votes. This goal has been described as elusive on account of the many diversions money can take in response to "hydraulic" pressures. ${ }^{9}$ Indeed, I will consider the ubiquitous problem in market segregation of multiple points of leakage and the problem of detection. Where direct currency exchange is banned, more indirect routes for exchange are sought and exploited. ${ }^{10}$ So too for institutions generally.

5. See infra Section II.A.

6. See infra Section II.B.

7. These are markets that produce information intended to influence the use of currency, and thus decisionmaking, in the primary market.

8. See, e.g., McConnell v. FEC, 540 U.S. 93, 122-32 (2003) (discussing developments in campaign financing that led Congress to pass the Bipartisan Campaign Finance Reform Act to the Federal Election Campaign Act), overruled in part by Citizens United v. FEC, 558 U.S. 310, 365-66 (2010).

9. See Pamela S. Karlan \& Samuel Issacharoff, The Hydraulics of Campaign Finance Reform, 77 TEx. L. REv. 1705, 1713-17 (1999) (describing how, within the campaign finance system, "[m]oney, like water, will seek its own level").

10. See, e.g., Pablo Slutzky, The Hidden Costs of Being Public Evidence From Multinational Firms Operating in Emerging Markets 11 (2018), https:// ssrn.com/abstract=2928711 [https://perma.cc/TH98-KS4F] (describing Argentina's deployment of foreign exchange limitation in 2011 and the consequent black market); Michele Goodwin, Black Markets: The Supply and Demand of Body Parts 49 (2006). 
Surprisingly closely related conceptually is the market for players in European football, in which the Union of European Football Associations ("UEFA") serves as a regulator. ${ }^{11}$ There, so-called "financial fair play" rules represent an attempt to define the proper currency of power within the market and to sever that currency from power accumulated irrelevantly in other markets. ${ }^{12}$ The problem, somewhat counterintuitively, is that some team owners are win-maximizing rather than profit-maximizing, indulging a consumptive preference for owning a winning football team. The upshot is that vast sums acquired in other markets, like finance, petroleum, or political graft, can create a near-instantly competitive team without regard to the level of support the team otherwise enjoys among fans. That "natural" level of power, meaning the assignment of power consistent with a league's assumed purpose, would be gained from transactions like ticket sales, television contracts, and jersey sales-not the largesse of an owner who views possession of a football team as the conspicuous consumption of the world's most expensive racehorse. Under this framing, it is more apparent that the struggle over financial fair play, just as with campaign finance reform, reduces to disagreement concerning a league's purpose and, secondarily, to the practicality of segregation. I will discuss the nature of this problem and the reasons that a market segregation remedy has been attempted.

Other examples abound, including the market for public justice and the rules applicable to lawyers, judges, and litigants. Even by calling this a market, I may appear to be tilting the analysis toward a neoliberal understanding of public justice as yet another forum of warring preferences and exchange. That is not my intention. The ontological similarity of, for example, banking and insurance markets on the one hand and judicial systems on the other is in their shared identities as purposeful, regulated institutions intended to reach collective decisions. The investments, trade-offs, preference types, and other aspects of the justice system are different from those in other markets. It is these differences that necessitate the prevention of power in those markets from being deployed to gain decisionmaking power in the justice system. But it also works the other way: decisionmaking power in the justice system and other public, political systems is segregated from direct power in economic markets. The former leakage is what we usually call public corruption. ${ }^{13}$ The latter is influ-

11. See About the UEFA, UEFA, https://www.uefa.com/insideuefa/about-uefa/ (last visited Oct. 11, 2019) [https://perma.cc/582J-842F].

12. Protecting the Game, UEFA (Jan. 2, 2014), https://www.uefa.com/insideuefa/ protecting-the-game/news/newsid=2048884.html [https://perma.cc/NZV2-GJNQ] ("[UEFA] introduced Financial Fair Play measures aimed at bringing discipline, rationality and responsibility to clubs' financial management, and [to] curb the financial excesses which have endangered the existence of certain clubs.").

13. Public Corruption, Legal Info. Inst., https://www.law.cornell.edu/wex/public _corruption (last visited Oct. 6, 2019) [https://perma.cc/3N9A-4NBQ]. 
ence peddling, also corruption, but its primary harm is to the efficiencies of the markets in which officially accumulated power counts for "too much" among the array of private preferences and currency that constitute them. ${ }^{14}$

The institutional perspective also sheds light on other areas of decisionmaking in which the public evinces convictions that money should not determine a decision. I consider the problems of artists' moral rights and repugnant transactions in Part IV. As with the primary examples, these areas too are home to seemingly domain-specific argumentation about how decisions should be reached. Again, it is possible to see the segregation dynamic at work if the relevant decisionmaking structures are put into focus.

Finally, in Part V, I make some initial observations concerning when resort to segregation is likely in the general case. The primary considerations are whether the market's decisionmaking is necessarily entangled with another's and whether there is social convergence on distinct and incompatible purposes between the markets.

\section{The Problem}

What is a market? As with the concept of law itself, there has long been an effort to define the term and thereby to distinguish a market from other forms of social organization. ${ }^{15}$ Noting something distinctive about a set of particular instances of behaviors is to latch onto underlying patterns of cause and effect in the otherwise impossibly complex world of human interaction. To take all that is happening in a region of time, space, and certain human minds and call it a "market" adorns a physical cacophony with a label that suggests abstract regularity. One explanation for the discordant definitions and uses of the term is that the regularity we seek to identify differs depending on the purpose of our analysis. ${ }^{16}$

We will make progress by acknowledging from the start that whatever we mean by "market" is approximate. As with all theoretical descriptions of social activities, we seek not to understand exact reality but to build a useful model. ${ }^{17}$ The process of definition is one of creating an abstract thought-object that behaves sensibly within our broader model of society and thus enables prediction and understanding. In this Article, I ask how and when a society might choose to separate some of its intuitively recognizable decisionmaking structures

14. See, e.g., Patrick J. Dellay, Curbing Influence Peddling in Albany: The 1987 Ethics in Government Act, 53 Brook. L. ReV. 1051, 1051-52 (1988).

15. See Richard Swedberg, Principles of Economic Sociology 130 (2003).

16. $C f$. Daniel C. Dennett, The Intentional Stance 15-17 (1987) (describing the virtues in different scenarios of adopting the physical, design, or intentional stance).

17. See Christian Turner, Models of Law, 2018 U. ILl. L. Rev. 1293, 1311-16 (2018) (describing how models are used as representations of complex subjects). 
from others so that the former will operate more or less independently of the latter. The first step in doing that, in segregating markets, is to define these structures as theoretical objects. Let us begin by considering three approaches: the "strong market-ontology school," the "school of discrete spheres," and the "institutional models" approach I advocate here.

I will settle on the last approach and proceed to elaborate the functional distinctions among cooperative institutions, creating a typology of markets that illustrates their diversity, their kinship, and the ways they overlap, work together, and wall themselves apart. The initial goal of the "institutional models" theory is to shift our viewpoint, freeing ourselves of tacit assumptions about sharp ontological distinctions between markets and other forms, seeing the internal power structures and currencies of all institutions as variations on a theme, and following the germ of that idea to build a field guide of institutions as seen through the market lens.

\section{A. The Strong Market-Ontology School}

The first approach to defining markets I will survey arises from the efforts of sociologists and other researchers to achieve a clear distinction between the markets they wish to study and other social forms, such as corporate hierarchies and centralized social planning structures. ${ }^{18}$ I call their approach the "strong market-ontology school," because in pursuing their purpose of modeling well and with particularity those institutional forms they conclude are markets, they identify a definite category of human decisionmaking and distinguish it from others. Doing so, of course, makes a great deal of sense. By focusing on differentiating features, researchers may then use more specialized models to make predictions about how an institution bearing those features will behave. If one's goal, for example, is predicting the incidence of traffic accidents, modeling "car driving" rather than the more generic "vehicle operation"-which might include piloting planes, boats, and forklifts-will be the more useful approach. While I will not hew to this strong form of distinction, this school's functional categorization of institutional features will help determine when markets, understood in a broader sense, should be made to work in concert and when in isolation. So a sketch of this methodology is warranted.

Many strong ontological approaches begin with commonly held notions about markets. But even in ordinary talk, "the market" can have several meanings. Perhaps the simplest conceived, if not articulated, is "the socio-economic phenomenon which takes place in the market-

18. Eckehard F. Rosenbaum, What Is a Market? On the Methodology of a Contested Concept, 58 REv. Soc. Econ. 455, 463 (2000). 
place of a city or town."19 This sense of the word draws a connection between a location (the "place" in "marketplace") and a social activity involving exchange that predominates there. But, especially these days, casual conversation about "the market" is often about a social phenomenon itself, irrespective of place. So used, the term corrals a set of exchange-related behaviors into a unit of thinking, an object for discussion, not a reference to a location with special attributes. This theoretical but casual sense could be deployed extremely generally (e.g., the whole set of potential transactions one could engage in for money), ${ }^{20}$ merely generally (a particular subset of exchange opportunities defined usually by regularization of those opportunities), or specifically (the market in a particular stock, for example).

In a particularly clear and helpful analysis, sociologist Eckehard Rosenbaum describes three approaches-observational, functional, and structural-to identifying markets compatible with this more general and modern sense. ${ }^{21}$ Observational definitions require empirical phenomena together with the presence of stylized facts about what is observed. ${ }^{22}$ For example, one might insist there be an actual marketplace or physical exchanges of goods (empirical phenomena) and also insist there be some minimal stability of prices (stylized facts). If you observe these things, under this observational formulation, you are observing a market. ${ }^{23}$

Functional definitions instead look for a social activity that has a particular effect. ${ }^{24}$ Perhaps we define the market as the set of activities that together serve as an allocation mechanism. ${ }^{25}$ In other words, a market "is" the product of the invisible hand and whatever contributes to it. ${ }^{26}$ Or perhaps the market is whatever imposes an ordering or

19. Id. at 456 .

20. Note the circularity here. To define the market as money-based transactions, or, even if money is not used, those that could potentially be backed by money, is to beg the question. We decide to use money in a decisionmaking area precisely when we want the dynamics of other money-connected markets to influence this one. But when do we want that to happen? That is the basic question.

21. Rosenbaum, supra note 18 , at $458-60$.

22. $I d$. at 458 .

23. See id. at $458-59$.

24. See id. at 459 ("[F]unctional definitions focus on what the market does rather on what . . . the market is.").

25. See id.

26. See id. ("[T]he market is essentially regarded as an allocation mechanism (or more metaphorically as an 'invisible hand' as in Adam Smith's work) . ...."). Celebrated French mathematician and economist Augustin Cournot is often cited for his definition, given in a footnote: "It is well known that by market economists mean, not a certain place where purchases and sales are carried on, but the entire territory of which the parts are so united by the relations of unrestricted commerce that prices there take the same level throughout, with ease and rapidity." Augustin Cournot, Researches into the Mathematical Principles of the Theory of Wealth 51-52 (Nathaniel T. Bacon trans., London, MacMillan \& Co. 1897) (1838). As with most strong ontological formulations, Cournot's functional approach was conducive 
equilibrium of social activities-whatever creates prices. ${ }^{27}$ Thus, a market might be defined as a disaggregated social activity that has the effect of stably ordering competing desires with respect to a particular good or set of goods. ${ }^{28}$ In a way, functional definitions are also observational, but they depend more on observations of the effects of behaviors than on the behaviors themselves. The functionalist thus finds a market by observing outputs and identifying their causes.

Structural definitions identify networks of exchange and understand the market to include "mechanisms [that] structure, organize, and legitimate" those exchanges. ${ }^{29}$ The market therefore is the set of property rights, contractual rights, and enforcement regimes that surround exchanges and have the effect of identifying networks of exchange. ${ }^{30}$ Geoffrey Hodgson, for example, notes that the market is not just the exchanges themselves, because those exchanges are "facilitated and structured" by the social institutions that exist to legitimate them. ${ }^{31}$ Just as the legal system may be more usefully conceived as emanating from the rule of recognition and other secondary rules rather than just being the primary rules it then generates ${ }^{32}$ a market can be conceived as including the secondary social rules that define and support its primary activities.

Rosenbaum himself rejects these approaches, suggesting they do not internally cohere or are not separately sufficient to distinguish markets from other social forms, such as hierarchies, firms, central planning, and casual exchange. ${ }^{33}$ Rather, to assert there is a social object called a market is to claim there is something that can be theo-

to his purpose, creating a mathematical model of demand, in the chapter in which the definition appeared. Id. at 44-55.

27. See Rosenbaum, supra note 18, at 459-60.

28. See, e.g., D. Satz, Market and Nonmarket Allocation, in 20 International Encyclopedia of the Social \& Behavioral Sciences 9197, 9197-98 (Neil J. Smelser \& Paul B. Baltes eds., 2001). For the purpose of contrasting forms of social organization, Satz posits markets as "mechanisms for the production, circulation, and valuation of goods and services" that in fact are "efficient, impersonal, and oriented to individual preference and choice." Id. at 9197. Once so defined, we can model markets and observe "market failures" empirically as deviations from these characteristics. Id. at 9198-99.

29. Rosenbaum, supra note 18, at 460 (quoting Geoffrey M. Hodgson, EconOMics And Institutions: A Manifesto for a Modern Institutional EconomICS 174 (1988)).

30. $I d$.

31. Hodgson, supra note 29, at 174 ("We shall here define the market as a set of social institutions in which a large number of commodity exchanges of a specific type regularly take place, and to some extent are facilitated and structured by those institutions. Exchange as defined above, involves contractual agreement and the exchange of property rights, and the market consists in part of mechanisms to structure, organize and legitimate these activities. Markets, in short, are organized and institutionalized exchange.").

32. See H.L.A. Hart, The Concept of Law 94 (2d ed. 1994).

33. Rosenbaum, supra note 18 , at 461-62. 
rized, "in the sense of making general law-like statements about it." 34 If a market can be theorized at all, there should be some basic qualities that permit us to reach conclusions about what is likely to unfold as the market proceeds under various conditions.

For Rosenbaum, a market is a system of disaggregated, impersonal, competitive exchange. In his own terms, it is characterized by ongoing exchanges that are voluntary, ${ }^{35}$ specified, ${ }^{36}$ typical, ${ }^{37}$ regular, ${ }^{38}$ and competitive. The primary consideration here is that exchanges must be impersonal and based on stable desires for relatively well-defined goods, not primarily related to the impact of the exchange on the social statuses of the participants. ${ }^{39}$ This criterion is worth keeping in mind for what follows because it imposes by definition the very thing I wish to study: the segregation of power in one kind of market (perhaps a supposedly impersonal exchange) from that in others (social structures that have conferred heterogeneous levels of in-group status). If the goal is to define markets to enable the kind of theorizing that relies on both coherency of price and agents' actions being in furtherance of preference satisfaction, then it is indeed important to assume away infusions of irrelevant capital-and thus to have a theory of relevancy.

Rosenbaum's definitional exercise reflects a normative assumption that some forms of power should not be spendable in a market, even if we restrict our attention to the most conventional kinds of markets. For example, if money represents power in a market for grain, then the unfolding allocation of grain might be difficult to theorize and to predict if currencies other than money can chaotically substitute for or add influence to a participant's supply of money. Thus, by defining a market in a way that excludes this possibility, we are really embedding an unstated theory of the relevance of power. The true "market" for grain is a social object that is protected from power accumulated in arenas of social cooperation assumed to be irrelevant. ${ }^{40}$ While the def-

34. Id. at 464.

35. By voluntary, Rosenbaum means that there is a substantial enough possibility of exit that the fact that a bargain occurs conveys pricing information. Id. at 467-69.

36. By specified, Rosenbaum means something similar to the presence of explicit consideration on each side of a bargain, thereby excluding gifts and vague expectancies. It would also exclude relational contracts so poorly defined that they resist pricing. Id. at 466-68.

37. By typicality of exchange, Rosenbaum means the substantial similarity of the underlying substance of transactions viewed across large numbers of exchanges. Id. at 471. Again, this is functionally tied to the working of the price mechanism, which requires some stability of comparison.

38. Regularity is similarly tasked with identifying transactional similarity in the temporal dimension. Id. Here too, we look for exchange behaviors that give rise to price stability, not necessarily constancy but sufficient stability that transactions in the putative family of exchanges can be seen to be related.

39. Id. at $472-73$.

40. It is interesting that Rosenbaum's "most extreme case" on the competitiveness scale is one in which the buyer and seller are behind a modified Rawlsian veil. Id. at 
initional claim is only descriptive, there is an implied but substantial normative bite. ${ }^{41}$

The goal of all of these efforts-observational, functional, structural, and hybrid - is to identify a category of collective decisionmaking mechanisms that will be susceptible to a particular kind of analysis. To oversimplify: if there are exchanges of a good satisfying these sorts of definitions, then we will observe something like a price mechanism operating as an invisible hand. To know, therefore, the evolution of the decisionmaking system, we need only analyze individual decisionmaking in the face of such a price system. ${ }^{42}$ And to do that, perhaps we can use the rational actor model or a behavioralist modification of it. ${ }^{43}$ Then we would have a model of the defined category of social activity that can generate non-obvious predictions.

Rosenbaum's definition, for example, provides qualities that identify suitable candidates for a field of such modeling. As he acknowledges, these qualities are mere tendencies, things that can exist in greater or lesser measure within a conceptual grouping of behaviors, leading to "degrees of marketness" rather than a binary. ${ }^{44}$ But his multi-part definition helps us see that there is more than just a onedimensional spectrum of institutions with true markets lying at one end and institutions becoming less market-like the further away one gets. $^{45}$

A more realistic look at the broader mass of behavior sees four dimensions, not just one, of more or less: voluntariness, typicality, regularity, and competitiveness. ${ }^{46}$ Imagine a highly voluntary and competitive regime in which bidders compete for goods that are nothing like one another, other than that the same group of individuals is bidding. In this "steampunk" marketplace, ever more strange and rare

473. They do not know one another's identities or social status (though they do know their own) and therefore are ignorant concerning how the exchange will affect their power shares in the social arenas outside the market in which the exchange is occurring. Just as with an analysis of public justice, the veil exercise here is an attempt to isolate a participant's purpose to that which optimizes the collective endeavor under an assumed goal.

41. See id. at 463.

42. See, e.g., Richard A. Posner, Values and Consequences: An Introduction to Economic Analysis of Law 3 (Coase-Sandor Inst. for Law \& Econ., Working Paper No. 53, 1998), https://chicagounbound.uchicago.edu/law_and_economics/608/ [https://per ma.cc/H38Z-2V3D].

43. See, e.g., Christine Jolls, Cass R. Sunstein, \& Richard Thaler, A Behavioral Approach to Law and Economics, 50 STAN. L. REV. 1471, 1476-81 (1998).

44. See Rosenbaum, supra note 18, at 475 ("Consequently, an economy is not composed of markets on the one hand and non-market exchange situations on the other, but may include a variety of exchange situations from wholly unstructured singular exchanges at one end of the spectrum, through to 'idealtypical' markets at the other.").

45. Rosenbaum places various canonical non-markets at the opposite poles of each criterion: firms, central planning, casual exchange, and gifts. Id.

46. See id. at 479. 
objects are each judged anew for their unique utilities. Similarly, one could relax only regularity: maybe a world of revolving beanie-babylike fads, boom and bust. Or competitiveness, where there is some competition but where a lot of the best goods go to well-connected people at heavily discounted prices without ever "coming on the market."

Even though I do not adopt it for this analysis, the multidimensional approach helps illustrate the diversity of institutional forms that might commonly be called markets and, most critically, the diversity of mechanisms for achieving institutional purposes. My effort in this Article is more general: analyzing the legal segregation of institutions by forbidding exchange of what gives rise to power within each of them. Some institutions that interact and will be of interest to us fall quite far from the edges of the dimensions that Rosenbaum associates with markets. Nonetheless, the law must take account of them. A more inclusive concept than proximity to impersonal exchange is needed.

\section{B. The School of Discrete Spheres}

Rather than choosing to make a conceptual distinction between markets and non-market cooperation, we could instead understand all social decisionmaking structures as possessing internal power distributions that determine the decisions they make. After all, a legislature uses equally distributed votes and persuasion according to certain norms to reach discrete decisions, and an ice-cream vendor and its customers use cash and bilateral transactions to distribute a supply of ice cream. Both are instances of decisionmaking, and both are social. And importantly, both involve individuals using power they maintain within the institution to affect the institutional decision.

Viewing institutions as decisionmaking entities paired with internal, power-distributing rules will indeed be the approach I adopt here. At this general a level, however, it is not an entirely novel way of perceiving our social world. Distributive justice theorists in various disciplines have cast markets as part of a broader institutional universe composed of separate "spheres" of distribution and power. Michael Walzer is the most well-known proponent of this description, from which he generated an associated theory of justice. ${ }^{47}$ The spheres of Walzer's model each distribute "different goods to different companies of men and women for different reasons and in accordance with different procedures." 48

In Walzer's landmark typology, there are three primary distributive principles - free exchange, desert, and need-that he argues underwrite the criteria used in the various spheres of social decisionmak-

47. See generally WALzer, supra note 1 .

48. Id. at 26. 
ing. ${ }^{49}$ His project was to advance a new and ingenious theory of distributive justice. Eschewing a lumped-together form of strict equality or Rawlsian maximin, Walzer defined a principle of "complex equality," under which "no citizen's standing in one sphere or with regard to one social good can be undercut by his standing in some other sphere, with regard to some other good."50

While the primary inquiry in this Article is not directly concerned with a theory of distributive justice, the descriptive side of Walzer's normative argument- "different goods to different companies of men and women for different reasons and in accordance with different procedures"-is compatible with the description here. ${ }^{51}$ The social world is an overlapping set of decisionmaking institutions, all with their own purposes and procedures tuned to those purposes.

Other scholars have similarly dissolved the market/non-market distinction to see many more institutional shades. Jon Elster, for example, has built a typology of allocative techniques and justifications from empirical observations of the distribution of various goods, such as kidneys, the burden of military service, and education. ${ }^{52}$ And sociologists Luc Boltanski and Laurent Thévenot have described "six different frameworks of justification: civic, market, inspired, fame, industrial, and domestic, which each contains their own principles of evaluation. ... [A]s a justificatory framework the market is constantly in conflict with other established ideologies and social norms." 53 Indeed, this way of understanding the social world, as composed of separate domains, goes back to Max Weber and almost certainly beyond. ${ }^{54}$

Mapping these domains and charting their characteristics is a field of active research. Ben Wempe and Jeff Frooman have examined various social domains, charted their identification by other theorists, mapped between various social values and compatible allocation mechanisms, and suggested how these variables should be related. ${ }^{55} \mathrm{In}$ the domain of healthcare, for example, Wempe and Frooman identify

49. Id. at 21-26.

50. Id. at 19 .

51. Id. at 26.

52. See generally Jon Elster, Local Justice: How Institutions Allocate Scarce Goods and Necessary Burdens (1992).

53. Kari Karppinen \& Hallvard Moe, What We Talk About When We Talk About "The Market": Conceptual Contestation in Contemporary Media Policy Research, 4 J. INFO. Pol'y 327, 333-34 (2014) (emphasis omitted) (discussing LuC BOLTANSKI \& Laurent Thévenot, On Justification: Economies of Worth (2006)).

54. See, e.g., Ben Wempe \& Jeff Frooman, Reframing the Moral Limits of Markets Debate: Social Domains, Values, Allocation Methods, 153 J. Bus. ETHICs 1, 5 (2016) ("Weber's conceptualizing of the various social domains may, in turn, have ultimately been related to the distinction between a public and private sphere in ancient Greek philosophy.") (citing MAX WEBER, Religious Rejections of the World and Their Directions, in From Max Weber: Essays in Sociology 326 (Hans Heinrich Gerth \& C. Wright Mills eds., 2012)).

55. Wempe \& Frooman, supra note 54, at 5-11. 
values of need, equality, and, subordinately, efficiency. They then argue these values give rise to certain compatible allocation techniques, applying them to the problem of the supply of kidneys for transplantation. ${ }^{56}$

The discrete spheres approach can enliven us to the reality that social decisionmaking occurs simultaneously in different aspects of our social lives and according to very different methods. However, its emphasis on discretization may rely too strongly on the supposed separateness of domains and on the existence of unitary social meanings within domains to advance an analysis of segregation. Indeed, some recent scholarship has questioned the focus on discrete distributive principles within discrete spheres, recognizing that real societies do not maintain only one method of provision per good. ${ }^{57}$ Rutger Claassen notes that Walzer's, and others', principles of distribution do not follow from an exhaustive taxonomic theory but seem drawn instead from conventional understandings, and so any constraints on allocation such principles entail may be as arbitrarily drawn as the principles themselves. ${ }^{58}$ And, within spheres, we often observe multiple means of distribution and attitudes toward distribution. ${ }^{59}$

Instead of the usual spheres approach of identifying a shared social meaning of the good in question and then matching a distributive method with that meaning, ${ }^{60}$ Claassen argues for what he calls "complex pluralism," in which multiple modes of provision are analyzed for how they jointly achieve ends that are themselves justified. ${ }^{61}$ For example, public education exists alongside private education, with, at some level of generality, many of the same practices and purposes attributed to each. Healthcare, massages, food preparation, jokes, and so many other social activities span separate domains within which alternative currencies of power operate. Our account of a society's global norms of distribution of power must therefore describe a complex sea of interacting institutions, some distributing similar, if not identical, goods. It must further face up to the reality that whether, for example, one sees "an educational system," separate public and private systems, individual school districts, or single classrooms as the units of analysis is a choice of perspective, not an authoritative description of some underlying reality.

56. Id. at $9-10$.

57. See, e.g., Rutger J.G. Claassen, Institutional Pluralism and the Limits of the Market, 8 Pol. Phil. \& ECON. 420 (2009).

58. Id. at 422 .

59. Id. at 426.

60. Id. at 428 .

61. Id. at 428-35. For Claassen, these ends are measured by an agent-capability theory. $I d$. at $430-31$. 


\section{The Institutional Models Approach}

Disagreeing in the abstract about the meaning of a word is plainly ridiculous. This will not be an argument about what a market "really is." Nor am I driven, as the strong market-ontologists are, to isolate particular, exchange-based institutions for separate analysis. Rather, with the school of discrete spheres, I observe that decisionmaking institutions that are stable, price-governed, and exchange-based are only one type among a broader family of collective decisionmaking structures. Moreover, institutions that reach decisions by aggregating and ratifying individual exchanges and institutions that reach decisions by, say, voting, are often more similar in their internal power dynamics than the labels they bear suggest.

Appreciating the larger set of institutions that reach decisions based on some evolution of internal power dynamics will illuminate how regulations stitch institutions together or rend them apart. But unlike the school of discrete spheres, I do not see isolated spheres but a web of institutions maintaining separate rules of both power usage and inter-institutional power exchange. That web's information-exchanging institutions are neither fundamental nor ontologically separate. Rather, they are merely perceived, or modeled, as such, depending on the purposes and perspective of the perceiver. ${ }^{62}$

Indeed, the very same activities can be understood as occurring within institutions of different scales. And so, we can consider the market for consumer goods, the market for televisions, or only the market for large-screen televisions. We can analyze the market for House of Representative bills, the market for congressionally passed legislation, or the market for federal legislation. All of these markets, at their varying scales, are potential objects of analysis, capable of study when they are modeled at a particular level of detail and in relation to adjacent decisionmakers.

I begin with my own definitions of the following terms:

- Institutions are cooperating groups of people that, given a question, apply some reasons and produce outputs.

- Markets are institutions but viewed with their internal power structures. That is, a market is a conceptual object that consists of both an institution and a representation of the power its con-

62. This approach bears some similarity to Luhmann's theory of organizations as social forms constituted by decision communications. For Luhmann, organizations only exist as decision communications, and they therefore are constantly producing and reproducing themselves. Critically, these decisions, like all communications for Luhmann, require interpretation (or understanding) to exist. See, e.g., David Seidl \& Hannah Mormann, Niklas Luhmann as Organization Theorist, in OxFORD HANDBook of Sociology, Social Theory and Organization Studies: ContempoRARY CURRENTS 137-40 (2014). But I am not yet prepared to explore the deeper connections with Luhmann's work. 
stituent entities possess to affect the institution's decisional output.

FiguRE 1.

Institution / Market

Issue
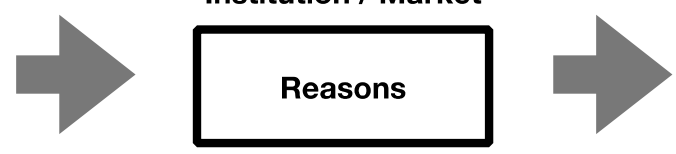

Decision

One could begin from a different perspective, perhaps describing decisionmaking institutions as possessing explicit or implicit voting rules, rules for recognition and governance of agents, due process rules of various sorts, and other attributes - all of which would sound in a public register. Under this view, even ordinary economic markets are composed of "legislatures" whose members "vote" with dollars. After all, private contracting parties write binding law and submit to a constitutional law of structure and rights, the body of law we teach as "contract law." We just call that law by different names than that which governs institutions we locate in the public sphere. ${ }^{63}$

We gain a different set of insights into cooperation by instead looking through the other end of the scope and characterizing decisionmaking institutions by their recognition of currencies of power, their rules of currency exchange, and other attributes that sound in a private, market-like register. The "market" approach to understanding the sea of overlapping cooperative structures of society is just that, an approach. It is a way of understanding cooperation, not a special category of cooperation.

I propose the following features, or types of rules, as sufficiently descriptive and distinguishing to characterize decisionmaking structures at the level of analysis at which law typically engages: (1) currency definition, (2) decision rules, (3) redistribution rules, (4) rules concerning secondary influence markets, and (5) currency exchange rules. Identifying these rules within a market generates an external description, meaning one concerned with objective features that explain to an observer how a market functions. An internal description would focus, instead, on the purposes and compromises that have drawn the participants together and have led them to organize in this way.

63. See Christian Turner, Law's Public/Private Structure, 39 Fla. ST. U. L. Rev. 1003, 1033-42 (2012) (explaining the symmetry between the secondary rules that govern the making of public and private laws). The rule recognizing a validly made law in the public sphere focuses on legislator identity and legislative procedure. In contracts, it is voluntary agreement among those who will be bound (unanimity rather than majoritarianism). Id. Viewed this way, the legal system's rules of recognition, whether for publicly or privately created laws, are tuned to the types of laws we wish various institutions to make and to policing for the problems institutions typically have. 
The table below suggests some options for each type of rule. Let us consider each type in turn and in greater detail.

TABLE 1.

\begin{tabular}{|l|l|}
\hline \multicolumn{1}{|c|}{ Rule Type } & \multicolumn{1}{c|}{ Examples of Options } \\
\hline Currency Definition & Explicit or implicit \\
\hline Decision Rules & $\begin{array}{l}\text { Threshold or continuous, disaggregated or } \\
\text { centralized }\end{array}$ \\
\hline Redistribution Rules & $\begin{array}{l}\text { Temporal dimension (never, delayed, } \\
\text { immediate, continuous, or discrete); degree } \\
\text { (none, partial, discrete) }\end{array}$ \\
\hline $\begin{array}{l}\text { Secondary Influence } \\
\text { Market Regulations }\end{array}$ & $\begin{array}{l}\text { Bans, limitations, registration and } \\
\text { identification, laissez faire }\end{array}$ \\
\hline $\begin{array}{l}\text { Currency Exchange } \\
\text { Rules }\end{array}$ & None, dyadic, hermetic \\
\hline
\end{tabular}

\section{Currency Definition}

One thing an institution's constitutive rules must do, whether written or not, is to provide a method to assess the kind and amount of power that individuals possess to affect the group's decisions. Such rules can range from an explicit one-person, one-vote rule to rules that are usually described as protecting private property and recognizing binding exchanges of that property. The electorate for a local representative and the members of a democratic legislature are examples of the former. Participants in a local real estate market, buying and selling lands and buildings, are examples of the latter. Both institutions assign power to individuals and recognize valid evolutions of the distribution of that power. Thus, each market contains a "currency," though of different types, and rules for the use of those currencies.

Currencies, as I conceive them, are conceptual objects employed by a modeler of instances of cooperation. They are not necessarily discrete symbols of power recognized from the internal point of view of a market participant. Nonetheless, each such participant does in fact maintain some power, some ability to affect (if not effect) a decision, and that power is either explicitly represented (in capital or voting share, for example) or at least is potentially representable and thus susceptible to external representation as an imputed currency (perhaps as an externally gauged measure of influence).

In markets that use money to allocate goods, the currency of power is obvious. The more money one has, the greater the ability actually to effect a distribution that is consistent with one's preferences. Similarly obvious is the currency in many legislative markets, the vote that can be cast for or against a proposal. In less formal decisionmaking 
groups, the currency may have to be inferred, its being only a model of more diffuse allocations of power. Perhaps in groups that appear to operate by consensus, complex power arrangements based on seniority and prior achievements in fact drive decisions, and we could endeavor to model the distribution of such power. In markets for judicial decisions, judges have a sort of monopoly and are sole possessors of currency. Yes, they are subject to the influence of lawyers and to criticism by other judges and the public. In other words, how they choose to deploy their power is influenced by the use of power in other markets. But we will take separate account, infra, of these secondary influence markets, the markets that influence how actors within a target market use the currency they possess.

\section{Decision Rules}

Any group action must be undertaken or implicitly approved by the group. Its rules governing actions and approvals are decision rules. Will there be a vote taken by all or only by some? Is there only one vote, or are there several layers of voting? Is the decision of a single member or some subset of members adopted automatically as the decision of the group, under some empirical conditions that must be found, as with private contracts? What behaviors by an individual will be required to manifest a decision by that individual?

The decision rules and the currency are related in that such rules define the currency's implications. Even if the currency exists as some physical object or is otherwise defined empirically, rules determine how its members recognize its use and how they justify decisions based on its use. In the market that distributes televisions in the United States, dollars are the currency. But decisions-which goods should be allocated to which people-are reached by certain behaviors with respect to that currency: namely a valid offer and acceptance as further defined by a state's contract law. ${ }^{64}$

\section{Redistribution Rules}

Suppose that participants, using some currency, reach a decision at a particular moment-for example, on a particular date the allocation of a certain good is what it is. What happens next? Some currency regimes are conservative in time, defining the allocation of currency in a manner that preserves the effects of the receipt and expenditure of the currency. Others are highly redistributive and thus disruptive of

64. Note the fact that, for example, some televisions are bartered does not much alter our satisfaction with a model of the television market that identifies dollars as the currency of power. This is so because so long as there are sufficiently numerous exchanges, the things bartered have a dollar value. Therefore, when analyzing the market, it will probably suffice to understand the distribution of dollars and rules for exchange in order to understand the market's evolution. 
their currency distributions, for example allocating currency anew after each decision.

Ordinary markets in consumer goods that use dollars as currency are examples of currency-conserving markets. Each valid exchange is recognized by the community as binding, and the movement of currency that effected the exchange is preserved. Taxation and public spending are the primary methods by which the distribution of currency is adjusted. ${ }^{65}$

In contrast, the market that produces the decisions of public legislatures uses the currency of a vote, and each unit of currency is confiscated and redistributed equally after every discrete decision. Note that these are just examples and that the potential for hybrids is one reason to take a more general point of view. Suppose a legislature worked by allocating one hundred votes to each member, each term. One could vote or not vote on each matter. Maybe a legislator is allowed only one vote on each matter, maybe more than one. Perhaps votes could be exchanged in some fashion. And only after the term would the remaining, unused votes be confiscated and then redistributed in the next term. ${ }^{66}$ Whether explicitly designed or inferred from observations of norms in action, currencies and their redistribution can be complex.

\section{Secondary Influence Markets}

For every individual with some power to affect a decision, there may be others interested in a decisional outcome and who wish to influence how that power is used. Advertising is an appeal to a consumer to use currency to direct resources to the production of the advertiser's goods or services. Each dollar spent on those goods is a vote for the advertiser's production as against other group efforts. Lobbying, campaign advertising, lawyering: all of these are efforts to change

65. For purposes of simplicity, I am glossing over the many ways a modern economy affects the value of fixed quanta of currency. See, e.g., Jane E. Ihrig, Ellen E. Meade \& Gretchen C. Weinbach, Monetary Policy 101: A Primer on the Fed's Changing Approach to Policy Implementation, Fin. \& Econ. Discussion SEries 2015-047 (June 20, 2015), http://dx.doi.org/10.17016/FEDS.2015.047 [https://perma.cc/H4SMLNRZ].

66. Decisions in the workplace governing which employees can take vacation time and when are often of this hybrid type. Federal government employees, for example, earn paid vacation days, a unit of currency capable of unilateral use, but some of these units are confiscated annually. See Office of Pers. Mgmt., Fact Sheet: Annual Leave (General Information), at https://www.opm.gov/policy-data-oversight/pay-leave/leaveadministration/fact-sheets/annual-leave/ (last visited Oct. 24, 2019) [https://perma.cc/ 6XRR-FWJY]. Employees may even donate leave to fellow employees who satisfy the conditions to become valid recipients. See Office of Pers. Mgmt., Fact Sheet: Voluntary Leave Transfer Program, https://www.opm.gov/policy-data-oversight/payleave/leave-administration/fact-sheets/voluntary-leave-transfer-program/ (last visited Oct. 24, 2019) [https://perma.cc/2PCE-ABWW]. 
the mind of a decisionmaker and redirect the use of his or her currency.

I use the term secondary influence market to refer to a market that produces information intended to affect the spending of currency in another market.

FIGURE 2.

Institution / Market

Issue

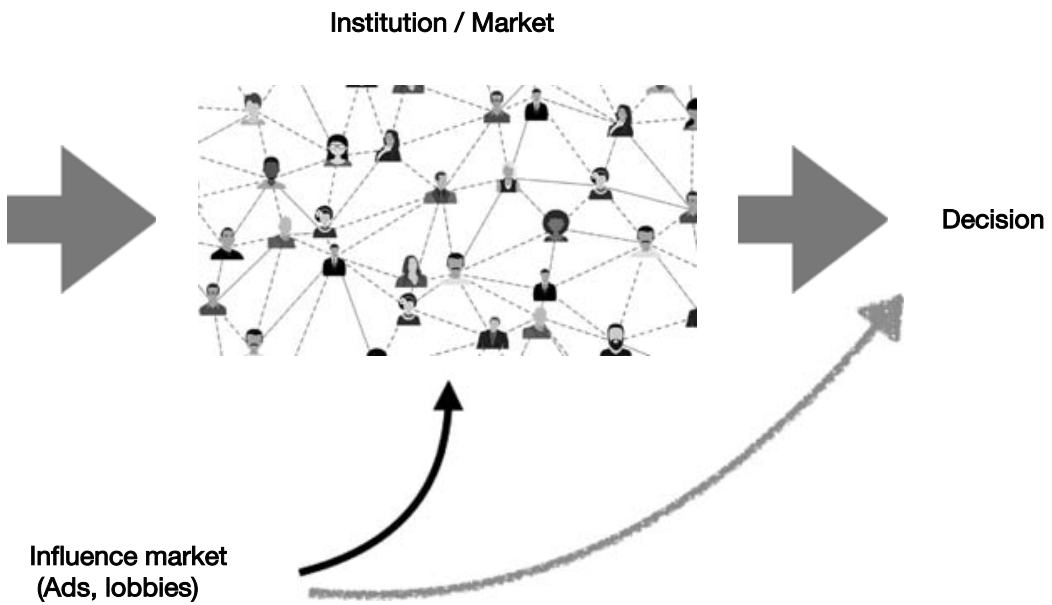

It is possible that a market's participants are so susceptible to the efforts of a secondary influence market effort that the market and its secondary influence market are analytically indistinguishable, the decisions of the former resulting entirely from efforts in the latter. If this is so, we can model the market's decisionmaking solely by analyzing the dynamics of the influence market.

This is the critique often given of our system of campaign finance, ${ }^{67}$ and political campaigning is difficult to distinguish from other forms of marketing. ${ }^{68}$ The outcome of an election may turn not on the decision reached through the spending of the electorate's highly redistributive and relatively currency-equal votes but through the spending of rival and unequally distributed dollars to vie for the attention of such voters. ${ }^{69}$ In such a case, even if votes cannot be paid for directly, ${ }^{70}$ the

67. See, e.g., Robert Reich, Saving Capitalism: For the Many, Not the Few 11-12 (2015) (discussing the influence money has over politics under current law).

68. See, e.g., Norman Peng \& Chris Hackley, Are Voters Consumers? A Qualitative Exploration of the Voter-Consumer Analogy in Political Marketing, 12 Qualitative Mкт. REs. 171, 173-76 (2009) (reviewing the marketing and political science literature comparing voters and consumers as marketing audiences).

69. The evidence concerning the extent to which this occurs is mixed and fascinating. Some studies support a connection between spending and persuasion (at least on some types of issues), some between spending and turnout, and some no connection at all. See, e.g., Thomas Stratmann, Campaign Finance: A Review and an Assessment of the State of the Literature, in 1 The Oxford Handbook of Public Choice 415, 418-21 (Roger D. Congleton, Bernard Grofman, \& Stefan Voigt, eds., Oxford Uni- 
influence market is causally connected with the decisionmaking market. Despite the formal segregation of the dollar-connected markets from the electoral market, the currency of the influence market, the dollar, can effectively be spent to influence election decisions.

\section{Currency Exchange and Segregation Rules}

Markets organize their currency rules and distributions differently, and one immediate family of questions concerns whether and how power in one market should be exchangeable with power in another, whether a market should be structured simply to mirror the power structure of another, or whether a market's power distribution should be causally walled off from another's. The consumer market in cars in the United States is nearly completely connected to the market in televisions. They use a common currency, dollars, and there are no obvious rules prohibiting the use of currency gained in one from affecting the functioning of the other. Note that this could be otherwise: if circumstances demanded, we could issue car coupons that are forbidden to be bought, sold, or exchanged for television coupons.

One reason it makes sense, though, to connect these markets seamlessly is that the production of consumer goods is rival and so a decision to produce more televisions ultimately comes at the expense of the capacity to produce more cars. ${ }^{71}$ And there is no pressing social reason to prefer a particular allocation of productive effort between them. The capacity of each might be expanded at the expense of the other, just as with all other connected markets, and, most importantly, we are happy with this dynamic. Individual consumers wishing to di-

versity Press 2019); Joshua L. Kalla \& David E. Broockman, The Minimal Persuasive Effects of Campaign Contact in General Elections: Evidence from 49 Field Experiments, 112 Am. Pol. ScI. Rev. 148, 148 (2018) (finding no effect of political campaigning and advertising on voter choice among candidates in general elections); Ryan D. Enos \& Anthony Fowler, Aggregate Effects of Large-Scale Campaigns on Voter Turnout, 6 Pol. ScI. \& Res. Methods 733, 733-35 (2016) (finding evidence that national campaigns can substantially increase turnout and that the mechanism is primarily in the form of "canvassing, phone calls, and direct mail," with little diminishing return for increasing such efforts). My effort here is to consider attitudes toward segregation in light of mismatches between a market's purpose and those to which it is connected. Whether to segregate ordinary markets from the market for campaigning depends a great deal on just how effective campaign markets are, whatever the mechanism by which they might be. For now, I note only that markets secondary to electoral markets exist and that a widespread assumption among voters is that they have substantial effects on the nature of the resulting representation. See, e.g., Rebecca L. Brown \& Andrew D. Martin, Rhetoric and Reality: Testing the Harm of Campaign Spending, 90 N.Y.U. L. REV. 1066, 1089-91 (2015).

70. A bar on direct payment is a segregation rule preventing the use of power in all the dollar-connected markets in the electoral market. See infra Section III.B.

71. Of course, other production may fall at the expense of both. 
rect their own limited resources should, we have concluded, mediate the devotion of social resources to these efforts in a Hayekian way. ${ }^{72}$

The dynamic, depicted in the figure below, is one in which power obtained in one market, for example by successfully satisfying television acquisition preferences, can be easily exchanged for power to influence allocation in the car market. Between the two efforts is a currency exchange, turning television power into car power as if between U.S. dollars and euros. By using exactly the same physical currency, this exchange is perhaps as low a transaction cost method of coupling the markets as can be imagined.

FIGURE 3.

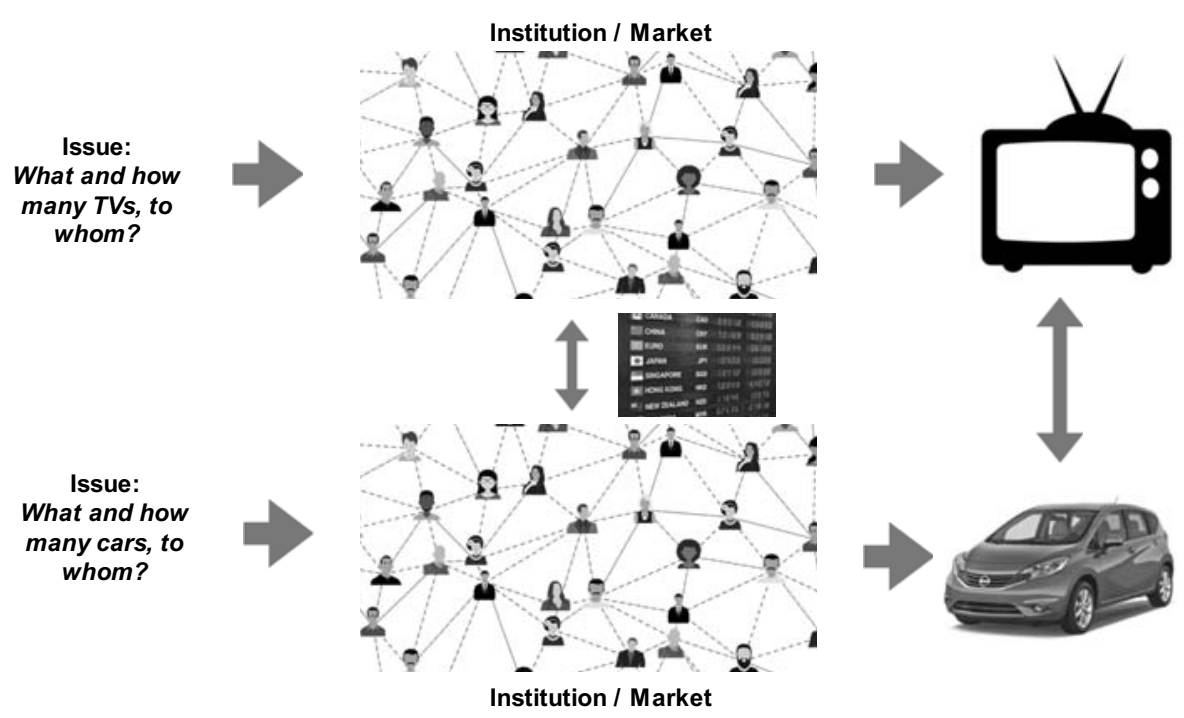

There are other instances, though, in which free currency exchange not only fails to serve a market's purpose but thwarts it. I will consider such examples in more detail in what follows. But an obvious one is a decision to connect the market for luxury automobiles (in which the widely exchanged dollar is the unit of decisional power) with the market for criminal adjudication (in which a judge and jury have been allocated detailed but circumscribed power over the decision). The very purpose of the market design in criminal adjudication is contrary to the incentives and allocation purposes in the market for cars, and so we have rules of judicial ethics, criminal bribery laws, and trial proce-

72. F.A. Hayek, The Use of Knowledge in Society, 35 Am. ECON. REv. 519, 526-27 (1945) (describing how the price system aggregates and transmits information from individual participants to adjust production and consumption without any single decisionmaker's needing to be conscious of the underlying patterns of availability and demand). 
dures that absolutely forbid currency exchange between these two markets. $^{73}$

In the figure below, we can visualize that forbidding currency exchange between the markets (the central no-entry sign), decouples the markets' decisionmaking (the rightmost no-entry sign). The institutional decision reached in the first market does not respond to power dynamics in the second. ${ }^{74}$

Figure 4.

Institution / Market

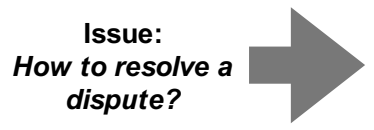

Judge / Jury
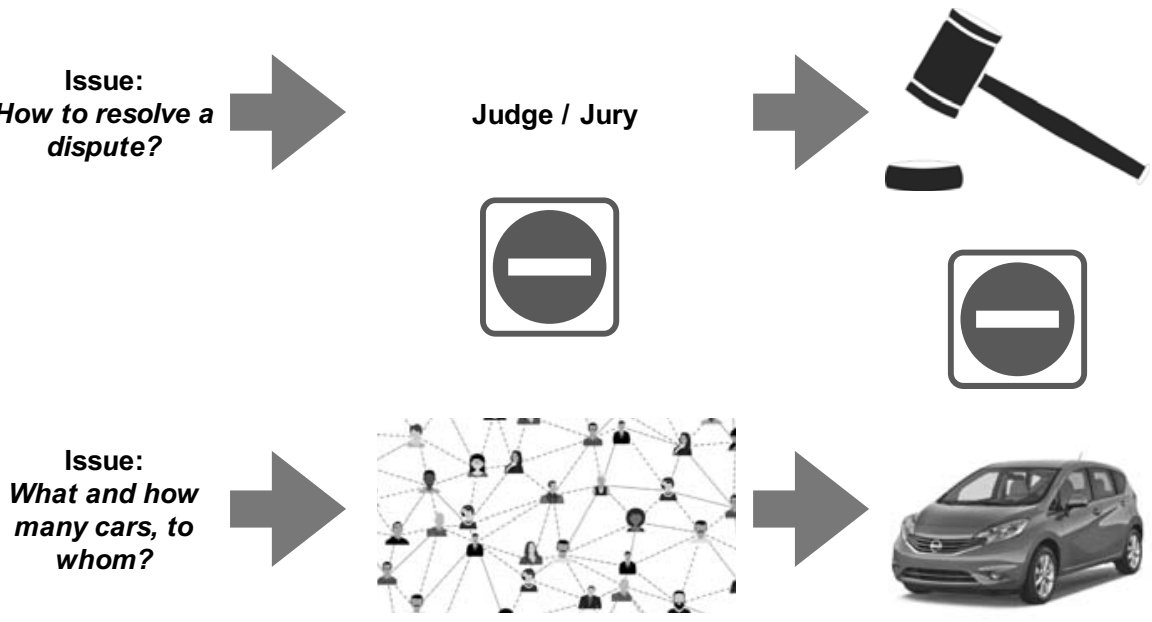

Institution / Market

\section{Summary}

A currency is a representation of power to induce others to join in effecting a collective decision. Dollars can be used to cause another to manifest the voluntariness that the collective deems sufficient to reallocate a good by contract. Dollars could also be used to induce another to join a voting coalition. So too, promised affection could be

73. See, e.g., 2C Guide to Judiciary Policy § 620.15, https://www.uscourts.gov/ sites/default/files/vol02c-ch06.pdf (last updated Dec. 14, 2010) [https://perma.cc/ 2VR8-93Q8] (discussing the prohibition of gifts to the judicial branch); see also CAL. Penal Code $\$ 92$ (2014) (making bribes to judicial officers punishable by imprisonment for two to four years).

74. In a remarkable article on the concept of bribery, Deborah Hellman identifies exchange across spheres of value as the critical fact bearing on our intuitions concerning the wrongfulness of political (and even familial) bribery. Deborah Hellman, $A$ Theory of Bribery, 38 CARdozo L. REv. 1947, 1971-72 (2017). But, even more interestingly and consistent with the institutional models approach I advance here, Hellman notes that determining spheres of value, and thus normative reasoning about exchange, is a social process, and the identification of these spheres is thus empirical. Id. at 1977-79. 
used, a potentially less rival sort of power, and perhaps less certain an inducement. A legislature has a currency of votes, which is rival by rule and reset after each vote to the initial, equal allocation. It has, as do consumer markets, thriving influence markets, both internal lobbying (where committee assignments, better offices, and promises of future coalitions influence vote spending) and external lobbying.

With these definitions and observations, a defense of my broad understanding of markets is apparent. It is helpful to use the same term "market" to describe these various institutions, despite their very different currencies and purposes, because people in fact attempt to exchange currencies across them all the time. There is surely a connectedness among nearly all markets, from financial derivatives to marriage. And even standard-issue economic markets of the sort we intuitively assume are and should be connected might have slightly different purposes from one another. ${ }^{75}$ So the desire to disconnect and segregate markets is sometimes obvious and primary, and it is sometimes subtler. But much confusion arises from thinking of the various decisionmaking structures as totally different in kind and incomparable. It is better to see what their differences actually are and to see our choice whether to connect or segregate them in light of these differences if our goal is to understand the larger system.

Public choice theory, for example, arises from the analysis of political institutions as if they were markets operating under many of the same principles as private, competitive markets. ${ }^{76}$ I want to examine society not as markets and other, different things that operate in some ways like markets-but as comprising overlapping collections of decisionmaking markets, all governed by internal and external laws that bind them together or divide them.

\section{Some ExAmples}

I now explore two examples of markets that have been the target of segregation efforts. They have aroused controversy in seemingly disparate social settings: the financing of political campaigns in the United States and the market for star players in European football.

75. Consider on the one hand markets in critical goods, like food, that are more likely subject to direct regulation in the face of dangerous scarcity and on the other hand markets in luxury goods that would proceed by normal exchange even if cut off from, say, food markets by a dangerous famine. This is to say nothing of the lesser forms of intrusion that control the use of resources within a market, governing thereby the rates and purposes of currency exchange, much like national currency controls, as in markets in housing subject to rent control. See, e.g., Daniel K. Fetter, The Home Front: Rent Control and the Rapid Wartime Increase in Home Ownership, 76 J. ECON. Hist. 1001, 1007-10 (2016) (describing the World War II-era federal rent control regulations, their purpose, and some resulting conversion by landlords, from one type of good, rental housing, to another, owner-occupied housing).

76. See, e.g., William N. Eskridge, Jr., Politics Without Romance: Implications of Public Choice Theory for Statutory Interpretation, 74 VA. L. REv. 275, 285-94 (1988). 
The lesson here is that the sort of abstraction that the institutional model of markets provides will help us to see the underlying similarity of the problems in these markets, typical responses to those problems, and problems with those responses.

The generic story goes like this. In each market, one can identify the market's point or purpose, even if there is not full agreement on the particularities of that purpose. Power accumulated in external markets characteristically interferes with that purpose when deployed directly to further the preferences of the one who wields it. Segregation efforts attempt to disarm such an individual, subjecting him or her primarily to the market's internally drawn rules of power accumulation and rendering useless power accumulated elsewhere. There are downsides. Formally closing the currency exchange between the internal market and the forbidden external ones is subject to potentially destructive loopholes or black-market exchanges. Furthermore, the less available currency exchange is, the more important the redistributive logic and justifications are within the market. It is in this way that the segregation of a market favors the market's incumbents. And so, while ideal segregation would protect a market's righteous purposes from external attack, it would also protect a market's corrupt purposes from external rescue. If normative contest would be beneficial, segregation is counterproductive. This effect has been a key point of criticism of segregation efforts in both the labor market in European football and the campaign finance market in U.S. national elections. In general, then, we find segregation urged to protect a market's normative logic. Critics cite two characteristic problems: (a) black-market leakage and (b) undesirable protection of incumbents. Let us start with the market that may be less familiar, the football labor market.

\section{A. Financial Fair Play}

\section{A Rough Description of European Football Leagues and Federations}

Compared to those of many professional sports leagues in the United States, European football federations' labor markets resemble ordinary free markets to a far greater degree. ${ }^{77}$ The competing and independent clubs associate with one another rather than operating as entities within a more singular corporate umbrella. ${ }^{78}$ For example,

77. See Richard C.K. Burdekin \& Michael Franklin, Transfer Spending in the English Premier League: The Haves and the Have Nots, Nat'l Inst. Econ. Rev., May 2015, at R4, R7-R8 (2015) ("There is no counterpart to the revenue sharing measures seen in all the major US sports leagues and the Premier League operates more like a free market ....").

78. A fascinating description of the history and current state of English football's league structures, inter-league and intra-league regulations as compared to most American sports is given in Stefan Szymanski And Andrew Zimbalist, National Pastime: How Americans Play Baseball and the Rest of the World Plays SOCCER, ch. 4-5 (2005). 
clubs contract directly with players, and this often entails bargaining with other clubs across the world to release players from existing contracts. ${ }^{79}$ On the income side, clubs earn their money in more traditional entrepreneurial terms rather than within a franchise system or a system of unitary ownership. ${ }^{80}$

Clubs' relative financial and decisionmaking independence creates the possibility that financially successful clubs will become dominant in sporting terms by outbidding other clubs for the best players, which in turn could bring more financial success, and so on in an ever-deepening cycle. Indeed, smaller clubs cannot compete with financial might of Europe's titans, like Real Madrid, Barcelona, Manchester City, Bayern Munich, or PSG. ${ }^{81}$ But independence creates opportunities for wealthy individuals to inject large amounts of cash to create an instantly competitive team. ${ }^{82}$ Examples in recent years in England include Russian billionaire Roman Abramovich's purchase and transformation of Chelsea F.C. and the purchase of Manchester City F.C. by multi-billionaire Mansour bin Zayed Al Nahyan. ${ }^{83}$

If we view the labor market in football from the more abstract vantage point of the institutions model, it might cause us to wonder what the purposes of this market are and whether its various currency exchanges interfere with those purposes. From the perspective of the federation, the purpose of competitive football is to maximize joint profits, with each club an asset or investment. Some owners, however, view their clubs more as articles of consumption rather than investment. They are win-maximizing rather than profit-maximizing. ${ }^{84}$ Even if one is cynical about modern sports, it would be naïve not to recog-

79. See, e.g., Andi Thomas, The European Soccer Transfer Market, Explained, SBNATion (July 28, 2014, 11:02 AM), https://www.sbnation.com/soccer/2014/7/28/ 5923187/transfer-window-soccer-europe-explained [https://perma.cc/SMF6-8E4V] ("Here's how a basic transfer works. Club 1 has a player. Club 2 wants a player. Club 2 and Club 1 thrash out an agreeable price, the player and Club 2 thrash out some agreeable wages, and then the transfer happens-the player's registration is transferred from Club 1 to Club 2, and he signs a new contract ....").

80. $I d$.

81. See, e.g., Calum Ross et al., Deloitte Football Money League 9 (2019), https://www2.deloitte.com/content/dam/Deloitte/uk/Documents/sports-busi ness-group/deloitte-uk-deloitte-football-money-league-2019.pdf [https://perma.cc/ CX86-5PLQ]. The revenue of each of these teams in the 2017-2018 season was about three times that of West Ham United, which, as the twentieth highest grossing team in Europe, itself earned more than nearly all other European clubs. Id.

82. See Burdekin \& Franklin, supra note 77, at R8.

83. Id. at R5.

84. Owners, of course, may exist along a spectrum from pure profit-maximization to potentially ruinous win-maximization.

The optimization problem facing the sportsman owner concerns the joint maximization of franchise value and the satisfaction derived from winning. The sportsman owner sacrifices franchise value for winning and expands the talent of his club beyond its value maximum. The resulting undervaluation of the franchise is the sportsman effect. In the limit, sportsman owners become win-maximizers, who are only constrained by zero profit. 
nize that many participants likely have at least some (and wish to demonstrate a great deal of a) spirit of fair play and desire for sporting glory. In sum, the motivations of the market's actors and their joint purposes may seem peculiar next to those of participants in, say, commodities markets. While it may not be entirely uniform, there is a set here of distinctive purposes against which the market's design can be measured.

\section{Key Market Attributes}

Let us focus on the market for football players in the terms we have developed thus far. The clubs are buyers, and the players are sellers. Once a player has a labor contract with a club, another club wishing to acquire the player must secure agreement with both the selling club and the selling player to effect a transfer. ${ }^{85}$ But should that be enough? Should there be other restrictions the league places on transfers to achieve its purposes, including those of promoting entertaining competition and the overall financial soundness of the league? This is, at bottom, a basic constitutional question concerning how the league decides to allocate players and deploy its resources to induce people to become players. Perhaps, for example, a league could conclude there should be limits on what a club can pay for a player. More generally, a league must decide what sort of decisionmaking power individual clubs should have in the ultimate decision regarding the distribution of players.

These structural decisions concerning player allocation are not without constraint from outside the market. Because players are free people and must be induced to play football, the structure as a whole must offer something to players that they can exchange in the seamlessly connected consumption markets at a level that exceeds (when combined with their inherent satisfaction with football itself) all other known opportunities. That is, players need something from this market that can be used to acquire money in ordinary consumption markets. The most obvious candidate for such a thing is money itself.

But the conclusion that the allocation decision regarding players and clubs must ultimately result in payment of money to players does not require that clubs pay that money, nor does it tell us whether the money paid to players should come from club or league resources. Some American leagues, for example, have a shared salary pool or such severe restrictions on what clubs can offer that labor contracting can be seen as a joint effort. ${ }^{86}$

John Vrooman, Sportsman Leagues, 62 Scottish J. Pol. Econ. 90, 91 (2015) (quoting Vrooman, A Unified Theory of Capital and Labor Markets in MLB, 63 SoUTHERN ECON. J. 594, 596 (1997)).

85. See Thomas, supra note 79 and accompanying text.

86. See, e.g., Dennis Coates, Bernd Frick, \& Todd Jewell, Superstar Salaries and Soccer Success: The Impact of Designated Players in Major League Soccer, 17 J. 
The European solution is, at least in overall form, the standard contract one. Clubs profit from their activities, and they pay money to players to help them generate further profits. This seems simple enough. Clubs earn money in various markets, including television rights, shirt sales, gate receipts, prize money, and the owners' personal resources. ${ }^{87}$ They use this money to buy players in the player market. ${ }^{8}$ So far, we have what seems to be a labor market that is seamlessly connected to other markets by sharing the currency of traditional money. To the extent there are any internal redistributive taxes and transfers, they arise chiefly from collective television rights. ${ }^{89}$ One way to see such contracts is as payments from popular and profitable clubs to other clubs that could not, on their own, negotiate television rights revenue to the degree it is distributed to them by the league.

In terms of our model, the generic European football labor market has the following form:

TABLE 2.

\begin{tabular}{|l|l|}
\hline \multicolumn{1}{|c|}{ Rule Type } & The Market for Players in European Football \\
\hline Currency Definition & Cash \\
\hline Decision Rules & $\begin{array}{l}\text { Dyadic agreement between clubs and } \\
\text { between club and player }\end{array}$ \\
\hline Redistribution Rules & $\begin{array}{l}\text { Weak, some redistributive sharing of } \\
\text { television revenue }\end{array}$ \\
\hline $\begin{array}{l}\text { Secondary Influence } \\
\text { Market Regulations }\end{array}$ & None \\
\hline $\begin{array}{l}\text { Currency Exchange } \\
\text { Rules }\end{array}$ & None \\
\hline
\end{tabular}

Given that the league's product is competitive entertainment, it is in the league's interest that teams are able to compete on at least a

SPORTS ECON. 716, 719-24 (2016) (describing the salary scheme of Major League Soccer, the dominant league in the United States, as team-level salary capped, with an exception permitting each team a given number of "designated players" that can be awarded very high salaries but which salaries are charged against a team's salary cap at a fixed, lower amount).

87. See Ross ET AL., supra note 81 , at 2.

88. See Thomas, supra note 79.

89. See, e.g., Premier League, Premier League Value of Central Payments to Clubs 2017/18 (May 17, 2018), https://www.premierleague.com/news/691073 [https://perma .cc/36TT-MWW7] (detailing the sharing of television revenue among UK Premier League clubs, with significant equalization among clubs); see also David Conn, Premier League's Top Six Win Battle for Larger Share of Overseas TV Rights, GuARDIAN (June 7, 2018, 7:06 AM EDT), https://www.theguardian.com/football/2018/jun/07/pre mier-league-big-six-win-battle-overseas-television-rights [https://perma.cc/5FWLSGUB]. 
somewhat even footing. While dynasties and popular teams may actually increase fan interest, leagues that are not at all competitive will generally underperform financially. ${ }^{90}$ If internal redistribution rules are weak, outsized injections of capital from external sources might harm a league's general purposes.

\section{UEFA's Financial Fair Play Regulations ${ }^{91}$}

The free labor markets of European football created two perceived problems, each of which posed a danger of cascading into further problems. First, many clubs, and many well-known clubs, racked up high debts, a large portion of which was from transfer fees and player salaries. ${ }^{92}$ Second, fans and football officials objected to "financial doping," the injection of large amounts of capital generated outside football by wealthy owners. ${ }^{93}$

On the first point, Egon Franck documents factors that cause even rational, profit-oriented clubs to gamble on success and thus overinvest in players. ${ }^{94}$ But rather than creating an arms race, football experiences a "zombie race," in which clubs overspend to remain competitive but are not subject to the ordinary threat of dissolution, because they are kept alive by creditors' reticence to call in debts, government support, and infusions from wealthy owners. ${ }^{95}$ The league may be entertaining, but its participants are the walking dead, financially.

90. See, e.g., Stefan Szymanski, Tilting the Playing Field: Why a Sports League Planner Would Choose Less, Not More, Competitive Balance 31-33 (London: Tanaka Bus. Sch. ed., 2005) (suggesting that regular rotation of dominant teams would help balance fan interest and annual attendance).

91. UEFA, the Union of European Football Associations, is, as its name suggests, an organization that governs international competitions in Europe and administers some of the most prestigious competitions in European football, including the UEFA Champions League. See Oliver Budzinski, The Competition Economics of Financial Fair Play 1-2 (Ilmenau Econ. Discussion Papers vol. 19 no. 85, 2014) (describing the structure of European leagues and UEFA's role as a "market-internal regulatory agency enjoying a monopoly position").

92. Tom Serby, UEFA's Financial Fair Play Regulations: The Devil is in the Detail, 5 Global Sports L. \& Tax Rep. 6, 6 (2014); see also Egon Franck, Financial Fair Play in European Club Football: What is it All About? 9 InT'L J. Sport Fin. 193, 196-202 (2014) (explaining the link between financial instability and public and private subsidies for risky financial management in sports leagues).

93. See Ariela Caglio et al., Does Fair Play Matter? UEFA Regulation and Financial Sustainability in the European Football Industry 4, 6 (Ctr. for Applied Research on Int'l Mkts., Banking, Fin. \& Regulation, Working Paper No. 2016-38, 2016) (explaining financial doping and sugar daddies).

94. See Franck, supra note 92, at 196 (pointing, inter alia, to exogenous prizes, strong correlation between investment and winning, large revenue differentials between clubs within a league and among leagues in a promotion and relegation hierarchy, and competition formats).

95. See id. at 196-202. 
The second problem, not entirely distinct from the first but perceived as a problem in its own right, is "financial doping." 96 "Doping" is a term that means, in its most general sense, the introduction of a foreign competitive advantage where it does not belong. ${ }^{97} \mathrm{~A}$ thing should be decided on certain grounds, and doping is the injection of other grounds into the system. "Financial doping" in sport, a phrase coined by Arsène Wenger, longtime manager of the Arsenal Football Club in England, means to suggest that money is somehow coming into football from an external and improper source. ${ }^{98}$

In many markets, "doping” just does not seem to be a particularly salient critique of allocation dynamics. It would be odd to suggest that rich people engage in financial doping of the television market when they purchase many televisions. Were their purchases so extensive that they raised the prices of televisions and related goods to a point that significantly affected the distribution of those goods, public concern would likely center on the distribution of resources generally. The difficulty in accessing televisions would then be a spark and a salient example rather than the whole issue in itself. Of course, one can imagine a world in which a cartel of rich consumers so corners the television market that the polity reacts by segregating television distribution from other markets. Yes, it is conceivable that a society might issue television coupons. But this would likely arise only at the point that distribution became so skewed that the thick layer of preferencesatisfaction justifications for market decisions was eroded to its core, bearing in the open a basic question of whether the availability of this good, here televisions, is important to the society. In football, where there is more convergence around distinctively collective purposes than there is in televisions, doping has a clear meaning: "Irrelevantly" obtained power unilaterally skews the decisionmaking apparatus away from those purposes. ${ }^{99}$

To combat these perceived problems, UEFA, Europe's governing football body, created new regulations on club finances, conditioning, among other benefits, participation in prestigious pan-European competitions on compliance. ${ }^{100}$ These so-called "financial fair play" regulations are simple in concept. Clubs must not run deficits. In particular, clubs must show that they "do not have overdue payables towards other clubs, their players, [or] social/tax authorities through-

96. See generally Hywel Iorwerth, Paul Tomkins \& Graham Riley, Financial Doping in the English Premier League, 12 Sport Ethics \& PhiL. 272 (2018).

97. See id. at 281.

98. See id.

99. See J. Christian Müller, Joachim Lammert \& Gregor Hovemann, The Financial Fair Play Regulations of UEFA: An Adequate Concept to Ensure the Long-Term Viability and Sustainability of European Club Football?, 7 InT'L J. SpORT Fin. 117, 123-24 (2012).

100. See id. at 118. 
out the season." ${ }^{101}$ Further, and more importantly, clubs must show that in the preceding three years they have a (nearly) net positive "income from football related activities and expenditures." 102 In other words, they must break even on footballing costs and revenues.

While this might sound like a purely financial regulation intended to counteract some tragedy-of-the-commons-like market failure, the purpose runs deeper. The key here is that the regulations require not just a profit in general, but a surplus of allowable, or what UEFA calls "relevant," income. ${ }^{103}$ And the relevant income, that which must sum to more than player salaries, transfer fees, and most other club costs, is defined by UEFA as, basically, money paid ultimately by fans interested in football. So gate receipts, television rights, advertising rights, prize money, and the like count as income for purposes of the rule. Injections of cash from wealthy owners do not. ${ }^{104}$

The key effort of regulations like these is to leave in place, without strengthening, the relatively weak redistributive systems of most domestic leagues while at the same time imposing segregation rules, a prohibition of currency exchange between the player labor market and all markets except those related to a club's footballing value. The rules let a club's player-buying power correlate with audience success. Teams that earn greater viewership, more shirt sales, and better licensing agreements are the ones with greater audience support. If the purpose of the cooperation (the league) is to maximize such support, then allocating players consistent with that support makes sense.

101. Serby, supra note 92 , at 7-8.

102. Id. at 8.

103. UEFA, Club Licensing and Financial Fair Play Regulations, art. 60 $\S 2$ (2018) ("If a club's relevant expenses are greater than relevant income for a reporting period, then it has a break-even deficit."). See also Angelo D'Andrea \& Donato Masciandaro, Financial Fair Play in European Football: Economics and Political Economy 3 (Baffi Carefin Ctr. for Applied Research on Int'l Mkts., Banking, Fin., \& Regulation, Working Paper No. 2016-15, 2016).

104. UEFA, supra note 103, at annex X(A) (defining "relevant income" as the sum of gate receipts, sponsorships, broadcasting rights, commercial activities, UEFA "solidarity" and prize money, other operating income, player sales to other clubs, profits from sales of tangible fixed assets, and "finance income" but excluding non-monetary credits, transactions with "related party(ies) above fair value," income from non-football operations not related to the club, income from players signed with the club, and bankruptcy-style protections from creditors). Expenses are similarly defined as "relevant" or not in order to allow non-relevant injections of capital to finance, inter alia, youth development, women's football, and community development. Id. 
Figure 5.

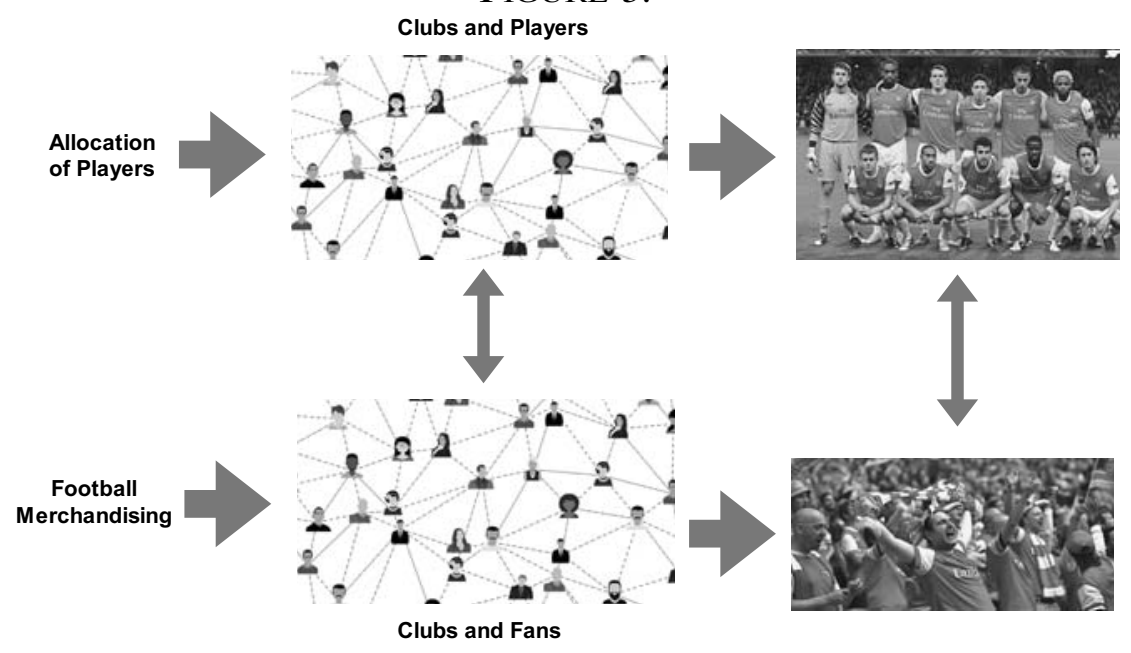

"Fair play" might also be construed as maintaining sporting competitiveness among teams. If so, then continual and significant redistribution of profits, perhaps going as far as to turn all clubs into discrete units of a single decisionmaking entity, might serve that purpose better. But substantial redistribution, by splitting all television proceeds equally, for example, could work against the "increasing audience support" purpose by skewing the allocation of players toward teams with weaker audience support and contravene audience taste for dynasties. ${ }^{105}$ So too could significant influxes of capital from sources unrelated to audience support hamper that purpose. A team with weaker fan support but with a win-motivated owner awash in oil riches might suddenly buy the best available players and curtail winning opportunities for the best-supported teams. Segregation of these markets attempts to preserve the distinctive, if not perfectly defined, purposes of the football league. 


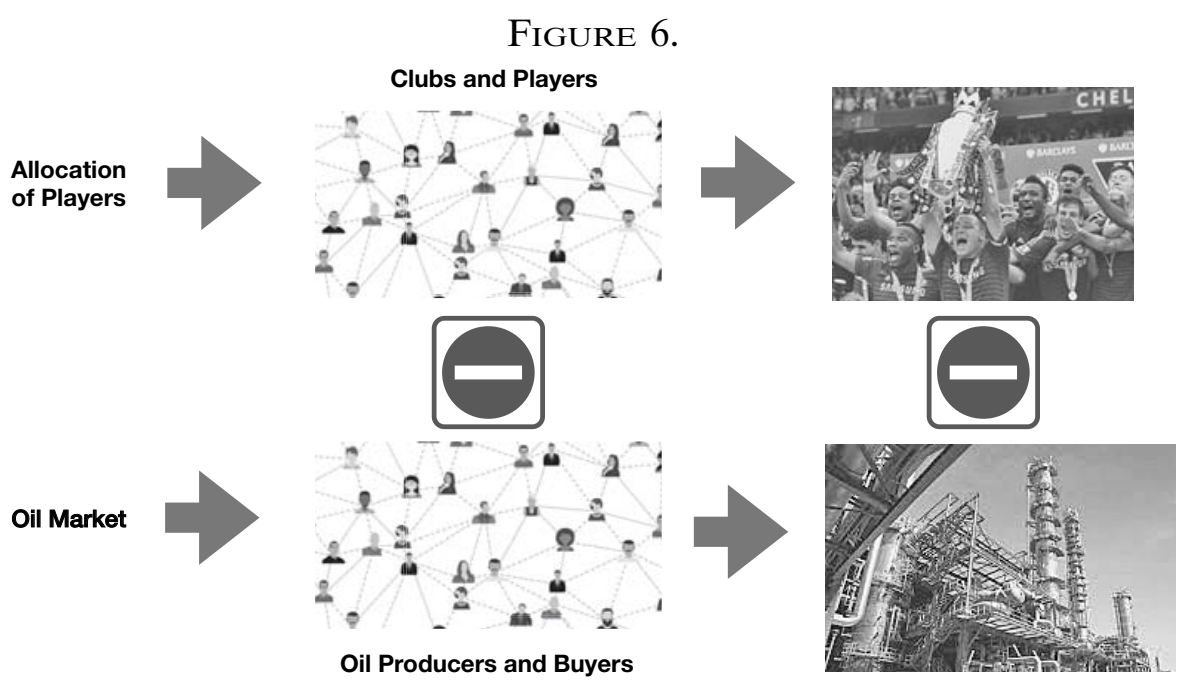

There are, of course, obvious rejoinders. First, segregation will be of little use or will unfairly burden those who comply if there is significant black-market exchange, meaning the illicit transfer from forbidden external markets to the internal market. In European football, many critics argue just this. For example, corporate entities, especially those somehow related to a club's owners, could overpay for stadium naming rights or jersey advertisements, smuggling in cash to balance the books. ${ }^{106}$ Money will respond to the hydraulic pressure applied by those with the means and desire to transfer it where it is wanted. Against this pressure, the resolve of the segregators will continually be tested as smugglers search for new loopholes.

But even if black-market leakage or loopholes could be controlled, the sudden infusion of success from a foreign currency exchange could do two things: (1) create new fans or make existing fans more supportive, thus changing the distribution of fan support within the league, and (2) increase the competitiveness of the league and drive more interest than a league dominated by a few incumbents. These observations amount to an internal critique of segregation, that segregation will in fact disserve the distinctive purposes of the league. Internal critics of segregation characteristically argue that exposure to the market's internal rules without recourse to external power will unfairly favor the market's incumbents. ${ }^{107}$ In doing so, they identify a basic

106. See Patrick J. Sims, The Circumvention of UEFA's Financial Fair Play Rules Through the Influx of Foreign Investments, 39 Nw. J. INT'L L. \& Bus. 59, 75-77 (2018).

107. See, e.g., Andrew Anthony, Football's Fat Cats Have Ended Any Hope of Equality and Fair Play, GuARdian (Sept. 20, 2014, 5:30 PM EDT), https://www .theguardian.com/football/blog/2014/sep/20/footballs-fat-cats-end-hope-equality-andfair-play [https://perma.cc/M7RM-6QR5] ("[T]he big, established clubs, who already make a lot of money, are entitled to spend it - as long as they don't go too far beyond 
conflict between the incumbent-entrenchment effect and the distinctive purposes that supposedly justify segregation. At the same time, they are necessarily, if implicitly, criticizing the market's internal redistribution mechanisms.

Economists have explored these claims. Some models of financial fair play show that big clubs will only become more dominant over time on account of the break-even rule's prohibition of capital injections from white knights. ${ }^{108}$ Others argue that wealthy individuals would look to gain control mainly of high-profile, winning clubs, and financial fair play rules therefore at least prevent the reinforcement of skewed competition. ${ }^{109}$

My point here is to observe how this sort of dispute arises. A market's purpose is perceived to be endangered by the exchange and use of foreign currencies. There is, therefore, an effort to prohibit such exchange. Dissenters then argue (a) that black-market leakage will render segregation ineffective or (b) that segregation only serves to reinforce existing inequalities within the market and that the market's weak distribution rules and segregation rules result from a failure of a political economy dominated by strong incumbents. Only power from outside the market can disrupt this grip on power and restore equality or competitiveness to the market.

The objective of this Article is not to resolve this conflict but to observe that our institutional model helps to see why these disputes are an unsurprising consequence of strongly purposed markets' adjacency to weakly purposed or differently purposed ones. And these fights are recapitulated under similar conceptual dynamics in other domains, like campaign finance, despite bearing different nouns and verbs.

\section{B. Campaign Finance Reform Efforts}

The problems of the campaign finance market are well-known. ${ }^{110}$ Elections for public office are supposed to reflect an aggregate preference of the electorate, and basic democratic principles require that each citizen has at least a roughly equal say in the outcome and a

their profits. But those clubs wishing to join them, who don't earn anywhere near as much, are restricted to their far smaller incomes. It's a charter for fat cats, a cartel in all but name.").

108. See, e.g., Markus Sass, Long-term Competitive Balance Under UEFA Financial Fair Play Regulations, (Otto Von Guericke Univ. Madgeburd, Faculty of Econ. \& Mgmt., Working Paper No. 5/2012, 2012).

109. See Franck, supra note 92, at 209-10.

110. See, e.g., Bruce Ackerman \& Ian Ayres, Voting with Dollars: A New Paradigm for Campaign Finance 3-11 (2002); David A. Strauss, What's the Problem? Ackerman and Ayres on Campaign Finance Reform, 91 CALIF. L. Rev. 723 (2003); Samuel Issacharoff \& Richard H. Pildes, Politics as Markets: Partisan Lockups of the Democratic Process, 50 Stan. L. Rev. 643, 688-90 (1998); Daniel H. Lowenstein, On Campaign Finance Reform: The Root of All Evil is Deeply Rooted, 18 HoFSTRA L. REV. 301 (1989). 
roughly equal ability to participate. These criteria entail at least somewhat proportional representation and that votes for representatives be equally distributed among the electorate. Our law reflects these conclusions. ${ }^{111}$

But the casting of ballots is not the whole of elections. Political campaigns strive mightily to influence the voters' casting of votes, the unit of power in the electoral market that voters have been allocated. Campaigning is a classic secondary influence market, a market allocating resources used to affect the spending of currency within the primary market. Supposing campaigns are effective and that their effectiveness increases with their resources, ${ }^{112}$ the market that distributes campaigning resources is causally connected to the outcome of elections themselves. It follows that if the above desiderata for the distribution of power among the electorate are to be satisfied, then individuals' ability to affect the relative balance of campaign resources must be controlled.

On the other hand, there is perhaps no area of public discourse closer to the heart of our reasons for protecting the freedom of speech than political debate concerning elections. ${ }^{113}$ The Supreme Court has concluded, perhaps wrongly, that the regulation of transfers of resources to a campaign is a regulation of an individual's speech. ${ }^{114} \mathrm{In}$ other words, not only are the outputs of the secondary influence market, campaign speech, protected by courts but so too is the currency exchange that turns other markets' dollars into units of power in this secondary influence market. Courts have often struck down efforts not only to suppress election-related speech but also to interfere with the ability to finance, and therefore allocate among campaigns, such speech. ${ }^{115}$

Let us analyze this problem in terms of our institutional model of markets. At bottom, there is a market for choosing public officeholders (or resolving ballot initiatives). Its currency is the vote. The decision rule is, generally, threshold majoritarianism. That is, the candidate or position receiving the most votes is selected. An individual vote is completely redistributive, meaning whether and however it

111. See, e.g., Gray v. Sanders, 372 U.S. 368, 381 (1963) ("The conception of political equality from the Declaration of Independence, to Lincoln's Gettysburg Address, to the Fifteenth, Seventeenth, and Nineteenth Amendments can mean only one thing-one person, one vote.").

112. See supra note 69.

113. Buckley v. Valeo, 424 U.S. 1, 15 (1976) ("[I]t can hardly be doubted that the constitutional guarantee has its fullest and most urgent application precisely to the conduct of campaigns for political office.") (quoting Monitor Patriot Co. v. Roy, 401 U.S. 265, 272 (1971). See also Hellman, supra note 74, at 1984 (noting that the Court has "treat[ed] contributing money to a campaign as one of the central ways that a citizen participates in politics ... plac[ing it] on par with voting").

114. Buckley, 424 U.S. at 16-20.

115. Id. 
is cast, it is confiscated after each decision and reallocated, one per eligible person, for each decision.

Last, currency exchange is nearly universally forbidden by law. ${ }^{116}$ Virtually no form of power gathered in other markets may be used to acquire more votes. ${ }^{117}$ This extends not only to those markets seamlessly connected through a dollar-based currency, but also to other markets. For example, the "Hatch Act" forbids most members of the executive branch from "us[ing] their "official authority or influence... [to] affect[ ] the result of an election." "118

To summarize:

TABLE 3.

\begin{tabular}{|l|l|}
\hline \multicolumn{1}{|c|}{ Rule Type } & \multicolumn{1}{c|}{ The Democratic Election Market } \\
\hline Currency Definition & Explicit vote \\
\hline Decision Rules & Threshold majority decision \\
\hline Redistribution Rules & Immediate, discrete resetting to single vote \\
\hline $\begin{array}{l}\text { Secondary Influence } \\
\text { Market Regulations }\end{array}$ & $\begin{array}{l}\text { Extensive campaigning, regulation of which is } \\
\text { subject to constitutional constraints }\end{array}$ \\
\hline $\begin{array}{l}\text { Currency Exchange } \\
\text { Rules }\end{array}$ & $\begin{array}{l}\text { Hermetic-virtually no allowable exchanges } \\
\text { with other markets }\end{array}$ \\
\hline
\end{tabular}

116. See Richard L. Hasen, Vote Buying, 88 Calif. L. Rev. 1323, 1324 n.1 (2000) (collecting federal and state statutes prohibiting exchanging votes for things of value, what Hasen calls "core vote buying").

117. Hasen helpfully surveys conventional rationales for this ban, including: a commitment to equality, concerns vote buyers would seek arbitrage opportunities for rent seeking, and concerns that commodification of votes will cause voters to see their power in more self-interested light. Id. at 1329-37.

118. Hatch Act, 5 U.S.C. $§ 7324$ (1993). As summarized by the Congressional Research Service:

All officers and employees in the executive branch, other than the President and Vice President, are still generally restricted in the following ways:

(1) They may not use their "official authority or influence for the purpose of interfering with or affecting the result of an election."

(2) They are generally restricted from soliciting, accepting or receiving political campaign contributions from any person.

(3) They may not run for elective office in most "partisan" elections.

(4) They are prohibited from soliciting or discouraging participation in any political activities by a person who has an application for a grant, contract or other funds pending before their agencies, or is the subject of an ongoing audit or investigation by their agencies.

(5) They are generally prohibited from engaging in partisan campaign activity on federal property, on official duty time, while wearing a uniform or insignia identifying them as federal officials or employees, or while using a government vehicle.

Jack Maskell, Cong. Research. Serv., 98-885, "Hatch Act" and Other Restrictions in Federal Law on Political Activities of Government EmployEES (1998). 
Next, let us turn to the thriving secondary influence markets paired to many elections. Campaigning is the spending of resources in order to influence how votes are cast. ${ }^{119}$ The campaigning market is highly regulated, but so too, through constitutional law, are its regulations highly regulated. ${ }^{120}$

TABLE 4.

\begin{tabular}{|l|l|}
\hline \multicolumn{1}{|c|}{ Rule Type } & \multicolumn{1}{|c|}{$\begin{array}{c}\text { The Political Campaign Market (Secondary } \\
\text { to the Election Market) }\end{array}$} \\
\hline Currency Definition & Cash \\
\hline Decision Rules & $\begin{array}{l}\text { Voluntary, dyadic transactions with media } \\
\text { companies }\end{array}$ \\
\hline Redistribution Rules & None \\
\hline $\begin{array}{l}\text { Secondary Influence } \\
\text { Market Regulations }\end{array}$ & $\begin{array}{l}\text { None, basically the marketing efforts of } \\
\text { various consultants (and grifters) }\end{array}$ \\
\hline $\begin{array}{l}\text { Currency Exchange } \\
\text { Rules }\end{array}$ & $\begin{array}{l}\text { Contribution limits for campaigns; looser } \\
\text { rules (non-coordination) on independent } \\
\text { expenditure campaigns }\end{array}$ \\
\hline
\end{tabular}

While the vote is the ultimate source of power within the election market, secondary influence markets are thought to be exceedingly important here. ${ }^{121}$ The campaigning market allocates the ability to marshal rival tools of persuasion to direct individual electors to turnout and to vote for one outcome or another. ${ }^{122}$ The basic question is how this latter allocation should be made and how allocations may be exchanged. Our market-design options range between absolute prohibition, where no market is even permitted to arise, to laissez faire, in which a market that uses dollars as a currency is permitted to decide to produce persuasion unlimited in kind and volume and is completely connected to all other markets that themselves permit connection.

Current U.S. law generally limits personal contributions to political campaigns but places no limits on expenditures by campaigns or by independent advocates. ${ }^{123}$ While the prevention of bribery and corruption has been held to be an important governmental interest, ${ }^{124}$ justifying limits on contributions to politicians, equalization of the

119. See Stratmann, supra note 69 , at 1 .

120. See id. at 2.

121. See supra note 69.

122. See id.

123. See Michael S. Kang, The Brave New World of Party Campaign Finance Law, 101 CoRnell L. Rev. 531, 537-48 (2016) (summarizing the state of constitutional limitations on campaign finance regulations).

124. See McCutcheon v. FEC, 572 U.S. 185, 206-07 (2014). 
ability of candidates or members of the public to speak on election matters has not been:

This Court has identified only one legitimate governmental interest for restricting campaign finances: preventing corruption or the appearance of corruption. We have consistently rejected attempts to suppress campaign speech based on other legislative objectives. No matter how desirable it may seem, it is not an acceptable governmental objective to "level the playing field," or to "level electoral opportunities," or to "equaliz[e] the financial resources of candidates." The First Amendment prohibits such legislative attempts to "fine-tun[e]" the electoral process, no matter how well intentioned. ${ }^{125}$

Thus, the Supreme Court has prevented regulation to achieve a purpose in the secondary influence market, equality of influence, that is widely perceived as indispensable within the primary market. Like other secondary influence markets, the actual purposes of the campaign-speech market are intended to bear on those of the primary market, the electoral system. Even though there are strict segregation rules preventing externally acquired power from being exchanged for votes in the election market, there is, under existing law, no serious bar on exchange between the campaign market and other markets. And so, while the route external power must take to be exchanged for the electoral currency of the ballot is indirect, passing through the secondary influence market, it may nonetheless get there.

Figure 7.

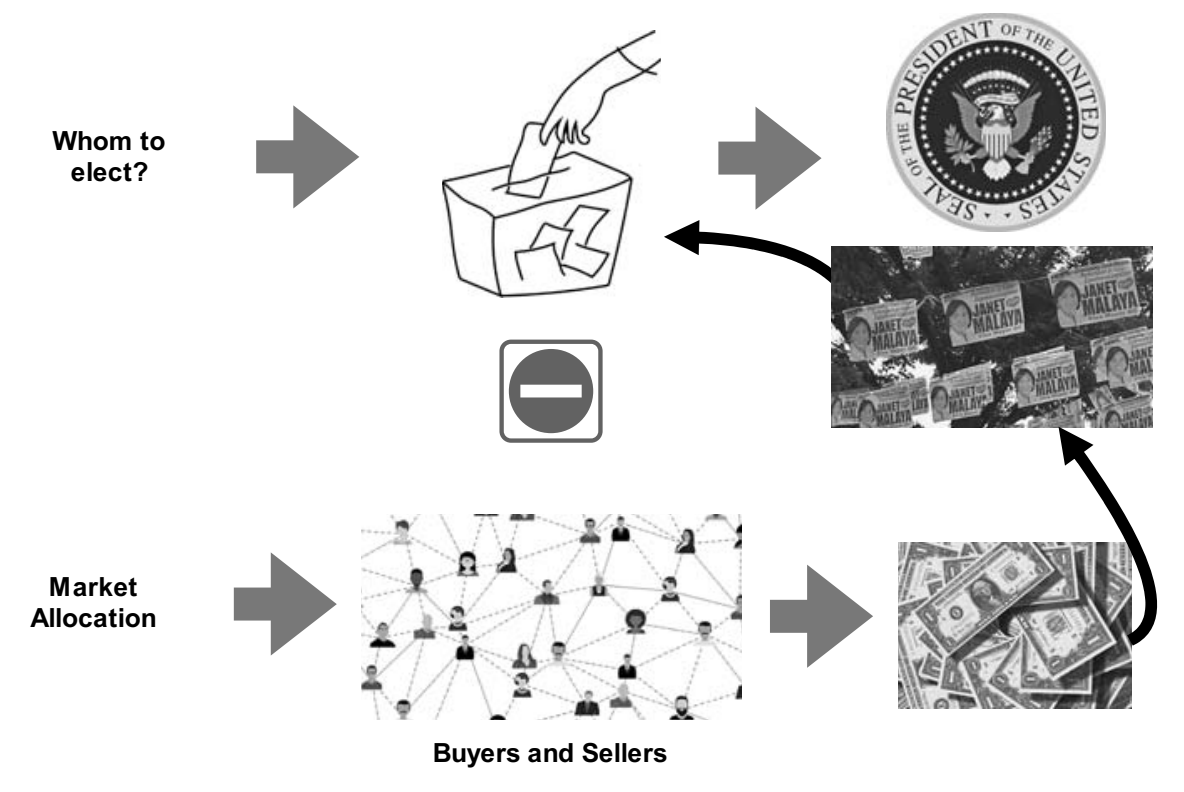

125. $I d$. 
Absent segregation rules between external markets and the campaigning market, there will be a normatively undesirable correlation between power in ordinary markets, power in the campaign market, and thus, ultimately, power in the electoral market.

It is, of course, not novel to observe that wealth devolved to campaigns can influence elections, but the perspective provided by the institutional model makes obvious that alternative design choices are available to us, that whether a market is serving its purposes or not is a matter with which we should be concerned and responsive, and that failures and unintended consequences are similar in nature across different sorts of markets. Just as the institutional model reveals the campaign-speech problem as the type of problem that will attract efforts at segregation, it also makes obvious that the counterarguments are instantiations of critiques of segregation rules more generally.

For example, one of the more widely known proposals to overhaul the campaign finance system on democratic grounds is the "patriot dollars" proposal of Bruce Ackerman and Ian Ayres. ${ }^{126}$ They propose that there be a large public fund for political campaigns but that the distribution of publicly provided funds be determined by individual voters. ${ }^{127}$ Each voter would receive fifty of these patriot dollars that could be given to the candidates for federal office of the voter's choosing. ${ }^{128}$ Their system would not strictly segregate the campaign-speech market, because contributions of ordinary dollars would still be permitted so long as they are made anonymously, as with patriot dollars. ${ }^{129}$ But exchange between patriot dollars and ordinary dollars would be forbidden. ${ }^{130}$

This design poses some obvious challenges, as Ackerman and Ayres acknowledge. For example, David Strauss points to the potential for liberty dollars to be "swamped" by directly contributed U.S. dollars. ${ }^{131}$ The critique here is one of imperfect segregation. If connection with an external market endangers the primary market's agreed-upon purpose, then one must either completely segregate the markets or at least substantially attenuate the external market's impact. This effort may fail for at least two generic reasons. First, a black market in currency exchange may arise. In the case of campaign-finance segrega-

126. ACKERMAN \& Ayers, supra note 110, at 4-9 (proposing (a) that donations be made anonymously, to combat quid pro quo corruption and (b) that contributions be in the form of public vouchers, equally distributed to members of the voting public).

127. $I d$.

128. $I d$. at $71-75,85$ (discussing a required allocation of the fifty patriot dollars among candidates for the House, the Senate, and the Presidency). See also Bruce Ackerman \& Ian Ayres, 'Patriot Dollars' Put Money Where the Votes Are, L.A. Times (July 17, 2003, 12:00 AM), https://www.latimes.com/archives/la-xpm-2003-jul-17-oeackerman17-story.html [https://perma.cc/Q8LR-5L7E].

129. ACKERMAN \& AYERs, supra note 110, at 71-75.

130. Id. at 16.

131. Strauss, supra note 110 , at 740. 
tion, a black market would amount to illegal campaign contributions. Second, if exchange is not forbidden but attempts have been made to render the suspect currency practically irrelevant by subsidizing another currency, as in the Ackerman and Ayres proposal, there is always the danger that the suspect currency will prove stronger and more determined than hoped.

Other critics of segregation of the campaign-finance market have similarly pointed to the leakage problem. Campaign information and speech take many forms, including news coverage. Should production of all forms of speech that might influence the decision of a voter, no matter the source, be limited by the resource allocation principles of a segregated, secondary influence market? That seems dangerous, and it further seems that any conceivable attempt to corral campaign-speech into a single, segregated market will inevitably engender many hard cases at the fuzzy boundary. ${ }^{132}$

Another generic segregation critique that has been leveled against campaign-speech segregation is segregation's danger of entrenching incumbents by full exposure to the internal market's norms without external recourse. ${ }^{133}$ If name recognition and free press (and perhaps favorable district lines in the case of some elections) advantage incumbents, it might take white knights to inject enough persuasive information into the speech market to ensure voters give a challenger a fair shake. ${ }^{134}$

Our interdisciplinary analysis captures, in general terms and as a consequence of more general dynamics, the particular notions expressed, for example, by Ronald Dworkin:

Citizens play two roles in a democracy. As voters they are, collectively, the final referees or judges of political contests. But they also participate, as individuals, in the contests they collectively judge: they are candidates, supporters, and political activists; they lobby and demonstrate for and against government measures, and they consult and argue about them with their fellow citizens. The individual-choice argument concentrates exclusively on citizens in the first

132. See Kathleen M. Sullivan, Political Money and Freedom of Speech, 30 U.C. DAvis L. REv. 663, 677-78 (1997) ("Popular attitudes about public policy do not exist in nature, but are formed largely in response to cues from political candidates and party leaders. Moreover, the institutional press-itself owned by large corporations commanding disproportionate power and resources-plays a large role in shaping public opinion. Any attempt to equalize campaign spending would still leave untouched any 'distortion' from the role of the press.").

133. See Strauss, supra note 110, at 740. Ackerman and Ayres argue that their mixed public and private system combined with anonymity requirements limit the danger of entrenchment under their proposal. ACKERMAN \& Ayres, supra note 110, at $35-40$.

134. See Sullivan, supra note 132, at 686-87 ("Incumbency confers enormous nonfinancial advantages: name recognition, opportunity to deliver benefits, publicity from the free press, and the franking privilege. To offset these advantages, challengers must amass substantial funds."). 
role and neglects them in the second. For when wealth is unfairly distributed and money dominates politics, then, though individual citizens may be equal in their vote and their freedom to hear the candidates they wish to hear, they are not equal in their own ability to command the attention of others for their own candidates, interests, and convictions. ${ }^{135}$

Indeed, we all play many roles in our society: family members, voters, buyers, sellers, workers, viewers, performers, and more. Society just is the union of all these cooperative instances, including the linkages among them. And the adjustment of these linkages is as important as setting the basic rules within each instance. ${ }^{136}$

\section{The General Pattern}

The parallels between financial fair play and campaign finance reform efforts hint at the power of abstract thinking. First, being clear about the degrees of freedom in market design shows clearly what is taken for granted in the markets we have. These un-designed features might cause conflict with the laudable purposes we otherwise attribute to these instances of cooperation. For example, why should success in financial markets give one usable currency in the market for the persuasion of others on matters we otherwise believe are appropriate for democratic decisionmaking? There is nothing natural about dollars themselves that should lull us into thinking that they belong everywhere.

Second, some dynamics that seem particular to a social structure might in fact be consequences of that market's design choices and reoccur in seemingly disparate social situations in which the same design choices are made. Here, we have seen that democratic social purposes in elections and competitive goals in high-profile sports are likely to be frustrated in the absence of substantial market segregation rules. However, we run into two familiar problems: black markets and tyranny of incumbents. Segregation will create pressure to find loopholes and engage in illicit currency exchange. And because strict market segregation rules tend to protect the market's incumbents, who by definition benefit from the market's internal rules, white-knight infusions of power from other markets may be needed if incumbency advantages are significant enough to be detrimental to the market's purposes.

135. Ronald Dworkin, The Curse of American Politics, N.Y. Rev. Books (Oct. 17, 1996), https://www.nybooks.com/articles/1996/10/17/the-curse-of-american-politics/ [https://perma.cc/LCG2-2YK4].

136. Deborah Hellman reminds us that which institution is charged with identifying the instances and adjusting the linkages is, ultimately, the critical question. Hellman, supra note 74, at 2017 (giving examples of parents deciding whether raking leaves is a familial obligation, Congress deciding the degree to which health care is a market or need-based good, and the Supreme Court's decision that it should determine the boundary between campaign finance and bribery). 
TABLE 5.

\begin{tabular}{|l|l|l|}
\hline \multicolumn{1}{|c|}{ Rule Type } & \multicolumn{1}{c|}{ Campaigning } & \multicolumn{1}{c|}{ Football } \\
\hline Currency Definition & Cash & Cash \\
\hline Decision Rules & $\begin{array}{l}\text { Dyadic with media } \\
\text { companies }\end{array}$ & $\begin{array}{l}\text { Dyadic with players } \\
\text { and source clubs }\end{array}$ \\
\hline Redistribution Rules & None & Weak (TV rights) \\
\hline $\begin{array}{l}\text { Secondary Influence } \\
\text { Market Regulations }\end{array}$ & None & None \\
\hline $\begin{array}{l}\text { Currency Exchange } \\
\text { Rules }\end{array}$ & $\begin{array}{l}\text { Contribution limits, } \\
\text { collusion controls }\end{array}$ & Financial Fair Play \\
\hline
\end{tabular}

\section{Moral Rights and Other Puzzling Markets}

The examples of labor markets in European football and the financing of American political campaigns demonstrated that viewing our social world as assemblages of connected markets can show that issues in disparate domains are conceptually isomorphic. The goods may be different, the actors and their goals distinct, but the resort to segregation and its potential ensuing pitfalls are similar. The theory, then, serves the usual purpose of such theories: to reveal apparently distinct phenomena as merely different aspects of the same thing. We have developed here a class of model, the institutional model of markets, that helps us to understand in simple and identical terms what would otherwise seem bespoke responses to particular problems.

But the theory can also help us see more simply the legal complexity within domains. Consider the problem of so-called moral rights, the rights retained by artists to prevent, inter alia, destruction or alteration of their works even when those works have been sold to others. ${ }^{137}$ There is no worldwide consensus on what these rights are, who should have them, or whether they can be waived. In the United States, for example, the Visual Artists Rights Act secures federal protection of moral rights. The Act primarily protects visual artists' reputations by giving artists control over whether their name is used in connection with an artwork. ${ }^{138}$ But the Act also gives such artists the right "to prevent any destruction of a work of recognized stature."139 These rights are non-transferable, exist only during the author's lifetime, and are waivable. ${ }^{140}$ In contrast, moral rights in France are perpetual, pass to an artist's heirs, and are non-waivable. ${ }^{141}$

137. See Amy M. Adler, Against Moral Rights, 97 CAlif. L. Rev. 263, 266-69 (2009).

138. 17 U.S.C. $\S 106 \mathrm{~A}(2012)$.

139. Id. $\S 106 \mathrm{~A}(\mathrm{a})(3)(\mathrm{B})$.

140. Id. $\S 106 \mathrm{~A}(\mathrm{e})$.

141. See, e.g., Code de la Propriété Intellectuelle [C.P.I.] [Code of IntelLectual Property] art. L121-1 (declaring that an author's moral rights "shall be 
One way to see these sorts of laws is as efforts to sculpt the extent of the "property rights" in works of art: one's right to a Picasso consists in this but not in that. Here, we are engaged in domain-specific calibration of the bundle of sticks that compose the ownership of art. ${ }^{142}$ Our theoretical commitments to autonomy, the social role of art, the connection between creator and creation, and more might inform our arguments concerning these rights.

We might, though, perceive that with respect to the distinct social decisions concerning the allocation of works of art on the one hand and whether to modify or destroy works of art on the other, different decisionmaking structures are called for. With respect to allocation, the argument might go, artistic effort comes at the expense of other forms of labor, and so it makes sense to connect that decision seamlessly with other markets that also allocate fruits of labor. Of course, not all societies may wish to atomize the decision whether to direct artistic effort in relative proportion to its demand. They may prefer patronage or very high public subsidy to direct the production of art that would not be achieved by individual decisions to sacrifice other goods.

Whatever institutional choice a society makes with regard to artwork-allocation decisions, it may perceive the choice whether to modify or destroy an existing work as a different decision for which its allocation market is ill-suited. If this were our choice, it would not be enough, as we have learned in the context of football and elections, just to create a different decisionmaking institution for destruction decisions. We must go further and institute some form of segregation from other markets if there is to be no necessary correlation between the destruction decision and power won in other markets.

At least a few ways we might do this are obvious. An absolute prohibition on destruction throws destruction decisions to legislatures or courts with the power to make exceptions or to amend, while at the same time segregating those decisions from financially successful actors to the same extent (however imperfect) as other such public decisions. We might instead allow destruction but require the artist's consent at the time of destruction. If we forbid payment for this decision, we have again chosen segregation, and we must here again be concerned with illicit currency exchange. If we merely require artist consent without forbidding payment, we have chosen not to segregate the destruction decision but have recognized two markets in two goods: the allocation right and the destruction right.

perpetual, inalienable and imprescriptible"); id. art. L121-5 (absolutely prohibiting destruction of the master copy of the final version of an audiovisual work). Of course, an artist is not required to enforce these rights, but neither is he or she bound by an agreement not to enforce them.

142. See Lior Jacob Strahilevitz, The Right to Destroy, 114 YALE L.J. 781, 794-96 (2005). 
The institutional model of markets gives us a way to appreciate that we have in fact established decisionmaking structures that may be more or less suited to the purposes we actually have. The argument from ownership, that I have a right to alter or destroy a work that I otherwise "own," has no persuasive power over us that is not obscured by and embedded in the complex concept of ownership. ${ }^{143}$ Under the institutional model, we debate rules concerning what decisionmaking structure should possess the right destroy. And we criticize those rules and the assignment of the decision to that institution for their fit with our social purposes. Moreover, we are attuned to the potentially destructive influence of other markets on this one. It just does not follow from our resort to ordinary markets in order to allocate works of art that we necessarily commit to such markets the power to destroy. That conclusion is clearer when we see markets in their more general aspect, as decisionmaking institutions complete with internal power arrangements and segregation rules.

We might also find our institutional vantage point helpful to understand taboo markets or "repugnant" transactions. Allocations of certain goods, including human organs and sex, by ordinary market transactions have been argued to "diminish[] or corrupt[]" them. ${ }^{144}$ While I leave many important details for future work, note that understanding these issues becomes easier when we start at the institutional design phase, eschewing the invitation to argue from a natural market baseline.

To begin with, the adjective "repugnant" in "repugnant transactions" is an umbrella term for various objections, including "corruption," meaning "violence" or "denigration" of "how goods are properly valued." "The football example shows that corruption objections of this sort may arise not only from the fact of market transaction simpliciter but from allocation accomplished with money from a wrong source. There, observing the purposes of player allocation led us to expect support for some types of traditional exchange, such as buying players with financial power gotten from gate receipts or shirt sales, but not those carried out with financial power gotten from nonfootball sources. It is not money or exchange itself but the connection between normatively incompatible power sources that caused some to cry "doping."

Ultimately, of course, the problem of distributing kidneys and sex, as with all else, is to decide on a collective mechanism for allocation, but the question of whether money can be used to do this is not bi-

143. Id. at 791.

144. See Michael Sandel, What Money Can't Buy: The Moral Limits of MARKETs 94 (1998), https://tannerlectures.utah.edu/_documents/a-to-z/s/sandel00.pdf [http://perma.cc/3AGQ-7NKN].

145. I. Glenn Cohen, On Repugnance, Distribution, and the Global Kidney Exchange, 175 J. Inst. \& Theoretical Econ. 20, 22-23 (2019). 
nary. Advocating for the prohibition of repugnant transactions is a call for the segregation of one market from some other markets. That often means barring cash, as in the noncontroversial example of barring bribes paid to judges and in the more controversial kidney market example. ${ }^{146}$ But sometimes it just means barring cash gathered in particular markets and maybe not every cash-based market (as in the football example). Or it can mean placing limits on the per-person volume of currency exchange between markets, as with limits on political campaign donations. For example, allowing only compensatory payments to surrogate mothers constructs a limit on the amount of currency that can be exchanged, and it does so, wisely or not, for a particular purpose. ${ }^{147}$ Such a rule suppresses raw ability to pay (power in cash-connected markets) as a controlling concern in surrogacy allocation. Constraining payment to compensatory rather than inducement levels is an attempt to preserve need and donative intent as the primary decisionmaking criteria.

When we focus our attention on the collision between the converged-upon justifications available to reach a decision and the reasons available for decisions in some other markets, many objections to "markets" are revealed as critiques of particular decisionmaking rationales, the power to apply them, and the exchange of the currency of that power for currency in a target market.

Consider Margaret Jane Radin's “domino theory," which observes that markets in a noncommodified good are problematic when it is not possible to maintain both noncommodified and commodified versions of the good at the same time. ${ }^{148}$ This may occur when market rhetoric infects our ability to enjoy "non-market" versions of the same good. ${ }^{149}$ While abstract, the point is easy to grasp concretely. Suppose, for example, that there were an unregulated market in children. And imagine being bombarded by advertising highlighting the attractive traits of various children, establishing an order of worth as with so many consumer products. It might be hard, the domino theory goes, to avoid having one's own relationship with a non-purchased child infected by the market's rhetoric, to continue thinking of their eye color, apparent intelligence, height, creativity, sulkiness, goofiness, and over-

146. Kim Krawiec, Kidneys Without Money, 175 J. Inst. \& Theoretical Econ. 4, 6 (2019).

147. See, e.g., Carol Sanger, Developing Markets in Baby-Making: In the Matter of Baby M, 30 HARv. J.L. \& Gender 67, 80-81 (2007).

148. Margaret J. Radin, Market-Inalienability, 100 HARv. L. Rev. 1849, 1913-14, 1922, 1925-26 (1987) (explaining the theory and inviting the reader to imagine whether non-commodified sexuality and non-commodified relationships with children would be possible were sex and children, respectively, to be fully commodified). The domino theory was one of three justifications for inalienability rules that Radin considered. The other two were coercion and direct moral objections to economic valuation of a good. Id. at 1909-12.

149. Id. at 1912. 
all personality as joyously individual rather than upsides and downsides as one would the features of a car. ${ }^{150}$

In the domino theory, we again see an argument for segregation arising from a supposed conflict between the normative purpose of the "non-market market" and the purposes of the broader markets seeking currency exchange. To have the allocation of children, for example, influenced by currency imported from other markets would disrupt the very purpose of conception and parental bonding in our noncommodified parenting culture.

Radin's focus on market rhetoric is a clue that domino-type harms to noncommodified markets arise indirectly through secondary influence markets. Indeed, the examples given above suggest that influence markets may erode the norms sustaining the noncommodified markets in children and in sex, even though the influence markets' purposes are to affect allocations in the parallel commodified markets. So even if we intend for prostitution to exist alongside noncommodified forms of sexual intimacy, influence markets allocating persuasive effort toward the former cannot help but influence allocations in the latter. Radin's prescription for non-ideal, incomplete commodification of sexual services, legalizing prostitution but outlawing middlemen and perhaps advertising, can be seen as protecting the segregation of the noncommodified market at the expense of some efficiency in allocation in the commodified market. ${ }^{151}$ Even this is imperfect, as Radin recognizes that so-called noncommodified, intimate sexual relationships are in fact influenced by power in other markets, mediated through partners' needs, wants, and unarticulated feelings of attraction. ${ }^{152}$

The institutional model of markets reveals this sort of dynamic as an instance of an unsurprising pattern. Where one finds markets, one finds secondary influence markets. Where one wishes to segregate, one faces black-market currency exchanges, entrenchment of incumbents, and decisions concerning how to regulate or even ban secondary influence markets. ${ }^{153}$ And so the importance of preserving the power arrangements one wishes to see prevail in the primary market must be evaluated next to the possibility and costs of realizing them given these difficulties. Where the suppression of black markets is costly, in resources or morals, and where their interference with primary market norms is substantial, one can expect segregation efforts not to get very far. Some criticisms of the official market in narcotics

150. Id. at 1925 ("If we permit babies to be sold, we commodify . . the baby itself [and] ... all of its personal attributes ....").

151. Id. at $1924-25$.

152. Id. at $1922-24$.

153. One can recognize here that regulations or bans of secondary influence markets, as with primary markets, do not ensure results in the world. Black secondary markets are a natural response to such suppression efforts. 
(a complex market mediated by physician-decisionmakers' determinations of need and safety) in light of thriving and often violent black markets are along these lines. ${ }^{154}$

\section{Segregation as a Choice}

With an abstract understanding of webs of markets, shorn of confusing particularities, and with a few examples in mind to guide our intuitions, let us consider the circumstances under which we should expect pressure for segregation regulations and when they might make sense.

First, to what degree does a decision of the market affect decisions made in other markets? A decision to produce a certain number of televisions and to distribute them in a particular way is a choice to devote a certain amount of labor and material to television allocation. Those resources are rival, and so this choice affects choices made in all other markets that depend on the same pool of labor and material. ${ }^{155}$ Factors common to both markets would impede segregation, even if desired, and would form an indirect communications network coordinating reasons. If two markets are coupled so that a decision in either constrains choice in the other, segregation is less likely to occur and to be successful.

Second, does the market have widely agreed-upon purposes, at some level of generality, that distinguish it? Most people do not have strong convictions about exactly how many televisions should be produced and exactly who should own which of them. This is a market in which the participants lack a strong sense of purpose distinct from that of many familiar markets: satisfaction of individual preferences to the extent practicable. Again, segregation from other such markets does not seem to be justified on norm-preservation grounds. The reasons that are grounds for decisions as to refrigerator allocation are not different in kind from those that ground television allocation decisions. And so we do not fear causal coupling.

Contrast the television market with the market for judicial decisions. First, adjudication's factors are rival with those of other markets in only the weakest sense. As with all human decisionmaking endeavors, adjudication requires labor. But the extent to which adjudication is rival with other markets, affecting through its decisions their decisions, is an attribute we usually endeavor to make explicit and to ground in justification. And while the purpose of the adjudication

154. See, e.g., Benjamin Levin, Guns and Drugs, 84 Fordham L. Rev. 2173, 2190-92 (2016) (discussing the social and economic consequences of the war on drugs).

155. This influence includes adding to the incentive to increase the supply of these jointly important resources. I do not mean to imply that television production is in zero-sum competition with, say, refrigerator production, only that the decisions in each sector are coupled. 
market is indeed contested in that people may differ concerning their theories of justice and judicial prerogative, there is in our culture a convergence on the impartial resolution of disputes, according to a distinctively legal process, as the general purpose of the judicial decisionmaking apparatus. It is the social gravitational field generated by the support for this purpose that makes the truly idiosyncratic rules of adjudication feel natural to a group otherwise conditioned to object to this mode of decisionmaking in other domains. In sum, unlike the television market, the adjudication market is not inextricably rival with markets in consumer goods, say, and it has a distinctive purpose that conflicts with the reasons for allocation in those markets.

A number of market design decisions thus follow from these facts. First, we should expect to see efforts to segregate adjudication currency from dollars. And, of course, we do. The market's currency, a monopoly of decisionmaking authority granted by virtue of judicial office, is fully segregated from nearly all other markets. Criminal statutes in every state bar exchanges of money for favorable decisions, for example. ${ }^{156}$ Furthermore, again consistent with our expectations, the judiciary's secondary influence market is highly regulated by rules of civil and criminal procedure, prohibitions on ex parte communications, bar requirements, and rules of evidence.

Notably, power in legislative markets can buy power in judicial markets. A legislature wishing to achieve patterns of future decisions in judicial markets can sometimes use its power to do so, directly by passing statutes and indirectly through the judicial confirmation power. If our model of social reality includes ordinary, dollar-based markets, legislatures, and the judiciary, then we could indeed trace influence from the legislature's secondary influence markets, governed by dollars, through the legislature, governed by votes, to the judiciary, bound by its interpretation of statutes. Whether this causal linkage is problematic depends on the extent to which it occurs and the socially specific extent to which the reasons in these various markets conflict.

Player markets in European football follow a similar pattern. We observe there a convergence around a set of purposes of the player allocation market distinct from the more generic purposes attributable to markets in oil and other commodities. Rivalry and a concern with heterogeneous needs and preferences may indeed justify the unrestricted currency exchange observed in these latter markets where cash is a standardized unit of control. But (a), the universe of professional football players is small, and it is likely that their opportunities in football (at the level at which financial fair play becomes important) are far more valuable than their next best opportunities. The goods being allocated are not exactly rival in the larger sense that

156. See supra note 73. 
their deployment here comes at the expense of their deployment in other markets. And (b), there is a notable convergence of distinctive purpose among market participants: maintaining financially stable and entertainingly competitive leagues-feeding the sense that clubs should grow with their support. Here, we need not ban dollars; we need only track them through accounting to manage the currency exchange between forbidden markets (those not relevant to organic support) and permitted ones (those where value is gained ultimately from sport).

The hypothesis I suggest here is tentative but plausible. Pressure to segregate a market will arise from the confluence of two sorts of facts: (1) an unusual level of convergence among its participants concerning its normative purposes and (2) little rivalry with respect to other markets, meaning that decisionmaking within the market is only very loosely, if at all, coupled with other significant markets.

TABLE 6.

\begin{tabular}{|l|l|l|}
\cline { 2 - 3 } \multicolumn{1}{c|}{} & \multicolumn{1}{|c|}{ Contested Purpose } & \multicolumn{1}{c|}{$\begin{array}{c}\text { Convergence of } \\
\text { Purpose }\end{array}$} \\
\hline $\begin{array}{l}\text { Rivalry with Other } \\
\text { Markets }\end{array}$ & $\begin{array}{l}\text { Connection (non- } \\
\text { segregation) }\end{array}$ & $\begin{array}{l}\text { Segregation pressure } \\
\text { met with } \\
\text { counterattack }\end{array}$ \\
\hline $\begin{array}{l}\text { Non-rivalry with } \\
\text { Other Markets }\end{array}$ & $\begin{array}{l}\text { No consensus on } \\
\text { segregation; internal } \\
\text { exchange; pluralism in } \\
\text { allocation }\end{array}$ & Segregation \\
\hline
\end{tabular}

\section{CONCLUSION}

The institutional description of markets discussed in this Article illustrates not a singular principle but an approach to understanding human cooperation. From familial decisionmaking, to homeowner associations, to the manufacture and distribution of cars, a society has many different sorts of decisions to reach at many different scales. If we identify a germ of similarity in the decisionmaking structures established in each, we can see more clearly why law and social norms sometimes tie different decisionmaking markets closely together and sometimes wall them off from one another, segregating them.

If instead, however, we label one thing a market and another collective decisionmaking structure something else and then conclude they should be governed differently and segregated because they are different things, we miss the opportunity to ask the essential question: Why is this structure unlike that one in a way that justifies their segregation? Assuming ontology from habitual use of words yields the inco- 
herent approach to law much criticized by the legal realists. ${ }^{157}$ Our labeling of one institution a "private market" and another a "public institution" or a different sort of private institution leads to what Felix Cohen called "transcendental nonsense," unless those labels represent some empirically distinct meanings that relate to our regulatory concerns. ${ }^{158}$ It is all too easy to deploy entirely different vocabularies, ones which in fact embed and hide different normative ideals, on the basis of intuition rather than function.

Indeed, through repeated use, we may lazily slide into thinking various cooperative structures are fundamentally different on account only of the rhetoric that predominates in and around them and which arises from baselines long ago taken for granted and ossified. For example, a market premised on enforcing "voluntary" exchanges of capital is identified as privately controlled and somehow not public. This labeling obscures the fact that the market almost certainly depends for its efficacy on collective enforcement, the details of which spin out countless mechanisms through which various "public" institutions in fact influence the market's decisionmaking. In what sense is such a thing different from a market of individuals who are chosen according to various qualifications and who reach decisions through equally distributed votes? To say the latter is public while the former is private is conclusory without more analysis and certainly not sufficient to count as a reason, on its own, for disparate regulatory treatment.

Perhaps the most critical change in understanding that comes with the shift in perspective I have advocated here is a new capacity to see, and perhaps an incapacity not to see, all our institutions in pursuit of purposes. Markets shorn of animating purpose and bearing connections to other markets that go unseen or naturalized by the forces of time and rhetoric lead us to act without mind, as if our world had always been so. But once we begin again to see purposes and to see currencies and other constitutive rules as yoked to these purposes, we can ask new questions and, as demonstrated in this Article, see old questions in a new light.

One of these questions, simultaneously new and old, is when to segregate decisionmaking markets. There are difficulties both conceptual (perceiving the markets and identifying their right purposes) and practical (effectively affecting the distributions of power, rules of internal power transfer, and rules of inter-institutional exchange). While these are indeed challenges, we can feel a little better taking even hesitant steps to meet them once we realize that we have been acting and stepping all along.

157. See Felix S. Cohen, Transcendental Nonsense and the Functional Approach, 35 Colum. L. Rev. 809, 820-21 (1935) (identifying some "magic 'solving words" in law and noting their circularity).

158. $I d$. 